\title{
Exploiting Race and Space: Concentrated Subprime Lending as Housing Discrimination
}

\author{
Benjamin Howell $\dagger$
}

\section{Prologue}

"Helen Latimore, a black woman, brought a suit charging racial discrimination in real estate lending by Citibank."' So begins an opinion affirming summary judgment against Latimore, a South Chicago homeowner denied a \$51,000 home equity loan because Citibank appraisers valued her home at $\$ 45,000 .^{2}$ The bank refused to accept a recent appraisal valuing the house at $\$ 82,000$ because the comparable sales on which it was based were taken from properties more than six blocks away. ${ }^{3}$ In concluding that no reasonable jury could find that the bank denied Latimore the loan because of her race, the court noted, almost as an aside, that Latimore eventually found a smaller loan at a higher interest rate.

Clyde Hargraves, reverend of the Little Ark Baptist Church in a predominantly black section of the District of Columbia, received an unsolicited telephone call from a mortgage broker who said he had heard of the church's financial trouble. ${ }^{4}$ The church was $\$ 70,000$ in debt. Reverend

Copyright $(2006$ Califomia Law Review, Inc. Califomia Law Review, lnc. (CLR) is a Califomia nonprofit corporation. CLR and the authors are solely responsible for the content of their publications.

$\dagger \quad$ J.D. candidate, School of Law, University of California, Berkeley (Boalt Hall), 2006. I would like to thank Professor Angela Harris, whose thought-provoking seminar inspired this project and whose insights and advice along the way made this final product possible. I am also indebted to Professor John Quigley for his comments from an economist's perspective, Kevin Stein for his thoughts early in the writing process, and Thomas Brom, whose file of articles first revealed to me the injustices of predatory lending. Finally, much thanks to the staff of California Law Review and especially Aimée Buckland and Meliah Thomas, whose thoughtful editing improved this Comment immeasurably.

1. Latimore v. Citibank Fed. Sav. Bank, I51 F.3d 712, 713 (7th Cir. 1998).

2. Id.

3. Id.

4. Brief for the United States as Amicus Curiae Supporting Plaintiffs, at 2, Hargraves v. Capital 
Hargraves, convinced by the broker that the church would have difficulty securing a smaller loan, pledged the church property to secure a $\$ 160,000$ loan, which, as he discovered only at the closing, included a $\$ 26,000$ origination fee and a $25 \%$ interest rate for the first four years. ${ }^{5}$ When he tried to reach the broker to complain about the fee, the broker's phone had been disconnected. ${ }^{6}$ After two years of struggling to make the payments the Little Ark Church declared bankruptcy; the mortgage broker foreclosed on the property and sold it for more than $\$ 200,000$ profit. ${ }^{7}$ The broker, Capital City Mortgage, directed its marketing almost exclusively toward borrowers in black neighborhoods: $94 \%$ of its loans in the District were tied to properties in majority black census tracts. ${ }^{8}$

\section{INTRODUCTION}

At an inner-city intersection, where globalized capital and free-market finance meet America's shameful history of racial segregation and subordination, a new and insidious form of racial discrimination lurks. Where lending discrimination once took a binary form-bigoted loan officers rejecting loan applicants because of their skin color-the new model of discrimination is exploitation. Unscrupulous lenders now prey on a history of racial redlining ${ }^{9}$ by aggressively marketing overpriced loan products with onerous terms in the same neighborhoods where mainstream lenders once refused to lend. ${ }^{10}$

Subprime lending, the extension of loans to those with less-thanperfect credit at higher rates, has developed almost overnight into a multibillion dollar industry. As the California Supreme Court recently recognized, by bringing access to capital to borrowers who do not meet the "prime" market's creditworthiness standards, subprime lending may have "enabled an entire class of individuals with impaired credit to enter the housing market or access the equity in their homes." subprime lending has also opened the door to "predatory lenders," who

City Mortgage Corp., 140 F. Supp. $2 d \quad 7$ (D.D.C. 2000) (No. 98-1021), available at http://www.usdoj.gov/crt/housing/documents/hargraves1.htm [hereinafter Brief for the United States].

5. Id. at $2-3$.

6. Id. at 3 .

7. Id.

8. Id. at 2 .

9. Throughout this Comment, "redlining" refers to the practice of denying the extension of credit to a specifie geographic area due to the income, race, or ethnicity of its residents. "Reverse redlining" refers to the targeting of persons for credit on unfair terms based on their income, race, or ethnicity. Reverse redlining typically occurs in communities that were once redlined. See United Cos. Lending Corp. v. Sargeant, 20 F. Supp. 2d 192, 203 n.5 (D. Mass. 1998).

10. See, e.g., Dan Immergluck, Credit to the Community: Community Reinvestment AND Fair Lending Policy in THE United STATES 267 (2004) ("The problem of poor access to mortgage loans has been transformed into a problem of poor access to fairly priced credit and one of frequently unsustainable credit promoted by abusive lenders.").

11. Am. Fin. Servs. Ass'n v. City of Oakland, 104 P.3d 813, 824 (Cal. 2005). 
resort to high-pressure sales tactics, half-truths, and outright fraud to convince borrowers to take out subprime loans with excessive fees and exorbitant interest rates. ${ }^{12}$ One economic model estimates that homeowners lose $\$ 9$ billion in home equity to predatory lenders annually. ${ }^{13}$ Policy makers face the difficult task of determining when a lender's destructive profitmaximizing practices cross the line of legality. ${ }^{14}$

The most disturbing aspect of the rapid rise of subprime and predatory lending is its significant racial and geographic concentration. A report by the United States Treasury and the Department of Housing and Urban Development (HUD) found that black borrowers were five times more likely to take out a subprime home equity loan than white borrowers ${ }^{15}$-a trend that persists at higher income levels. ${ }^{16}$ Moreover, a Federal Reserve Board governor noted that as many as half of subprime borrowers have credit scores that would qualify them for a prime loan. ${ }^{17}$ Together, these statistics suggest that black borrowers consistently overpay for home finance.

Subprime lending is geographically concentrated in the same minority neighborhoods once denied access to banks and excluded from federal

12. It is generally accepted that not all subprime loans are predatory, but that nearly all predatory loans are subprime.

13. Christopher A. Richardson, Predatory Lending and Housing Disinvestment 19 (Feb. 2003) (unpublished manuscript, on file with the California Law Review), available at http://papers.ssm.com/ sol3/papers.cfm?abstract_id $=338660$.

14. In the past four years, twenty-six states have enacted predatory lending legislation. Baher Azmy, Squaring the Predatory Lending Circle: A Case for States as Laboratories of Experimentation, 57 FLA. L. REv. 295, 295 (2005). The predatory lending debate, however, suffers from the difficulties of defining a "predatory" loan. Using lists of prohibited loan terms or interest-rate triggers to define predatory loans simply gives unscrupulous lenders a target to avoid. DEP'TS OF THE TREASURY AND Hous. and Urban Dev., Curbing Predatory Home Mortgage Lending 17 (2000), available at http://www.huduser.org/Publications/pdf/treasrpt.pdf [hereinafter HUD-TREASURY REPORT]. In addition, any list of predatory practices is destined to be incomplete because "bad actors are constantly developing new abusive practices, sometimes to evade new government regulation" and "a list does not consider the context in which the alleged abuse has occurred." Id.

15. HUD-TREASURY RePORT at 23. In this Comment 1 have artificially simplified America's multi-ethnie population into black and white. Contemporary segregation of blacks from whites is directly rooted in historic, state-sponsored discrimination. Whereas today so-called "ethnic" neighborhoods may be the result of residents' volitional housing choices, the continued segregation of blacks from whites may not be divorced from its historical causes. My argument that racially concentrated subprime lending constitutes housing discrimination is thus limited to subprime lending targeted at black borrowers or predominantly black neighborhoods.

16. Calvin Bradford, Risk or Race? Racial Disparities and the Subprime Refinance MARKET 3 (2002), available at http://www.knowledgeplex.org/kp/report/report/relfiles/ ccc_0729_risk.pdf.

17. Governor Edward M. Gramlich, Subprime Mortgage Lending: Benefits, Costs, and Challenges, Remarks at the Financial Services Roundtable Annual Housing Policy Meeting, Chicago, Illinois (May 21, 2004), available at http://www.federalreserve.gov/boarddocs/speeches/2004/ $20040521 /$ default.htm. Preliminary estimates by Freddie Mac suggest that between $10 \%$ and $35 \%$ of subprime borrowers could have qualified for a prime loan. Freddie Mac, Automated Underwriting: Making Mortgage Lending Simpler and Fairer for America's Families Chap. 5 (Sept. 1996), available at http://www.freddiemac.com/corporate/reports/moseley/chap5.htm. 
homeownership programs because of their racial composition. Although geographic discrimination alone is not actionable under the Fair Housing Act (FHA or Title VIII) ${ }^{18}$ if a lender exploits historic racial segregation by marketing higher-priced loans to minority neighborhoods to profit from borrowers' lack of other options, such profiteering may constitute actionable housing discrimination.

Successful pursuit of such claims will depend on two elements: (I) empirical data linking race, geography, and loan terms ${ }^{19}$; and (2) legal theories appropriate to the new exploitation paradigm of housing discrimination. Recently, district courts have accepted "novel, innovative and serious" ${ }^{20}$ arguments that depart from traditional housing discrimination doctrine developed to combat the old (binary) form of discrimination. Both the "exploitation"21 and "reverse redlining"22 discrimination theories rely on market analysis as well as historical and socioeconomic context to judge the legality of allegedly discriminatory lending. This Comment will argue that these two innovations of the FHA doctrine are better suited than current fair housing doctrine to meet the challenges of the new and more dynamic form of housing discrimination: the exploitation of past discrimination through geographically and racially concentrated subprime lending.

18. Discrimination based on an individual's geographic location does not violate the Fair Housing Act, which prohibits discrimination based on "race, color, religion, sex, familial staus or national origin." 42 U.S.C. $\$ \S 3604$ (a)-(b) (1968). More generally, fundamental guarantees of civil rights such as the Equal Protection Clause accrue to "people, not places." Reeder v. Kansas City Bd. of Police Comm'rs, 796 F.2d 1050, 1053 (8th Cir. 1986) (citing McGowan v. Maryland, 366 U.S. 420, $427(1961))$.

19. Such empirical evidence is forthcoming as the regulation implementing the Home Mortgage Disclosure Act of 1975 (HMDA), Pub. L. No. 94-200, 89 Stat. 1125 (1975) (codified as amended at 12 U.S.C. $\S \S 2801-2810(2000)$ ), now requires lenders to report information for loans priced above designated thresholds, in addition to the already mandated reporting of a borrower's race and the location of the property. See Joseph T. Lynyak 1II, Liability for Discrimination Claims Based on Revised Regulation C, 50 CONSUMER FIN. L.Q. 116 (2004). The Federal Reserve's initial analysis of the new pricing data for loans originated in 2004 concluded that, regardless of income level, blacks are three times more likely than whites to take out a high-cost subprime loan. Edmund L. Andrews, Blacks Hit Hardest by Costlier Mortgages, N.Y. Times, Sept. 14, 2005, at Cl. This new HMDA data linking race, location, and loan pricing is already drawing the scrutiny of regulators. In April 2005, New York Attomey General Eliot Spitzer opened a preliminary inquiry to gain "a clearer picture of whether discrimination is responsible for the higher interest rates that minority borrowers often pay." Eric Dash, New York Begins Inquiry Into Possible Mortgage Bias, N.Y. Times, Apr. 29, 2005, at C2.

20. Honorable v. Easy Life Real Estate Sys., 100 F. Supp. 2d 885, 888 (N.D. Ill. 2000).

21. The "exploitation theory" holds that a lender may be liable for housing discrimination if (1) a segregated housing market exists, and (2) the lender unreasonably exploits such market conditions. Id.

22. The "reverse redlining" theory provides for liability under the Fair Housing Act if (1) a defendant's lending practices are "unfair" and "predatory," and (2) the defendant either intentionally targeted its "unfair" and "predatory" loans on the basis of race, or its use of such lending practices results in a disparate impact on the basis of race. Hargraves v. Capital City Mortgage Corp. $140 \mathrm{~F}$. Supp. 2d 7, 20 (D.D.C. 2000). 
Running through this Comment a tension exists between the hallowed Anglo-American tradition of caveat emptor and an intuitive sense of fairness that similarly qualified borrowers should receive similarly priced loans. The American legal system is loath to evaluate the relative fairness of benefits freely bargained for. The U.S. regulatory philosophy of ensuring fair competition, but not fair results, is perhaps nowhere more evident than in the mortgage markets. Nonetheless, despite this hands-off regulatory approach, "there cannot in this country be markets or profits based on the color of a man's skin." 23 When free-market ideology confronts civil rights statutes, the statutes must trump. The doctrines interpreting the Fair Housing Act, a statutory scheme enacted to achieve "fair housing throughout the United States," 24 must evolve to meet the challenges posed by new forms of mortgage lending discrimination.

Part I of this Comment examines the historical roots of racially concentrated subprime lending, including the federally supported real estate appraisal system that intentionally placed black neighborhoods at the lowest end of the value spectrum. Part II discusses structural shifts in the mortgage market in the I990s and how these shifts led to the concentration of subprime lending in the same neighborhoods where banks once refused to lend. Part III addresses the shortcomings of traditional housing discrimination doctrine to combat the new exploitation paradigm of housing discrimination and argues that two new theories are better suited to the task.

\section{The History of America's Racial Geography}

Empirical research establishes that subprime mortgage lending is severely concentrated in particular geographic areas ${ }^{25}$ and amongst certain racial groups. ${ }^{26}$ This concentration is the direct result of historic racial

23. Contract Buyers League v. F \& F Inv., 300 F. Supp. 210, 216 (N.D. 11l. 1969).

24. 42 U.S.C. $\$ 3601$ (1968).

25. Paul S. Calem et al., Neighborhood Patterns of Subprime Lending: Evidence from Disparate

Cities, 15 Housing POL'Y DEBATE 603, 604 (2004), available at http://content.knowledgeplex.org/kp2/cache/documents/58732.pdf. In one study, researchers modeled loan data from seven cities in the years 1997 and 2002. Id. at 603 . After controlling for demographic and economic variables, they concluded that "neighborhood minority share is consistently significant and positively related to subprime share in both years." Id. See also Elvin K. Wyly et al., Has Mortgage Capital Found an Inner-City Spatial Fix?, 15 Housing PoL'y DeBate 623, 672 (2004), available at $\mathrm{http} / /$ content.knowledgeplex.org/kp2/cache/documents/58733.pdf. According to the authors' data, both race and geography are tied to the likelihood of receiving a subprime loan, and "[a] black person requesting a loan in a core gentrified neighborhood is more than twice as likely to end up at a subprime lender than an otherwise similar black person elsewhere in the metropolitan area." Id.

26. The 2000 joint HUD-Treasury report found that in predominantly African American neighborhoods $51 \%$ of refinancing loans were subprime compared to a mere $9 \%$ of loans in predominantly white neighborhoods. HUD-TREASURY REPORT, supra note 14, at 23. A borrower from an African American neighborhood seeking a home refinance loan is thus five times more likely to receive a subprime loan than a borrower from a white neighborhood. Id. Moreover, the higher 
discrimination by both private and state actors. Despite the passage of the FHA in 1968, the United States remains nearly as segregated as it was in the 1960 s. $^{27}$ Indeed, "among all areas of civil rights taken up during the 1960s, neighborhood segregation proved to be the most emotional and resistant to change"28 and today America's racial geography remains largely as it was in the $1940 \mathrm{~s}^{29}$ Furthermore, geographic income segregation is increasing, ${ }^{30}$ as is the racial wealth gap. ${ }^{31}$ Given this stark physical and economic segregation, if subprime lending is concentrated on the race axis, concentration along the geographical axis logically follows, and vice versa.

As financial transactions tied to real property, residential mortgages are inextricably linked to the political and racial geography of the United States and the country's history of state-sanctioned racial segregation. Today credit and banking markets remain highly segmented across racial and geographical boundaries. ${ }^{32}$ Because, as one study has shown, lender characteristics may be a better predictor of whether a borrower will receive a subprime loan than are borrower characteristics, ${ }^{33}$ disparities in the geographic distribution of prime lenders will affect the concentration of subprime lending more than the financial profiles of prospective borrowers in those areas. Moreover, the concentration of subprime lending is selfreinforcing: as the effects of high-interest rates and onerous loan terms further impair the creditworthiness of borrowers and increase neighborhood

concentration of subprime loans in minority areas persists when neighborhood income is taken into account: in upper-income African American neighborhoods nearly $40 \%$ of home refinance loans were subprime, compared to $5 \%$ in upper-income white neighborhoods and $20 \%$ in lower-income white neighborhoods. 1 .

27. See, e.g., Sheryll D. Cashin, Drifting Apart: How Wealth and Race Segregation are Reshaping the American Dream, 47 VILL. L. REv. 595, 596 (2002); Nancy A. Denton, The Role of Residential Segregation in Promoting and Maintaining Inequality in Wealth and Property, 34 IND. L. REv. 1199, 1201 (2001).

28. Douglas S. Massey \& Nancy A. Denton, American Apartheid: Segregation and the MAKING OF THE UNDERCLASS 191 (1993).

29. David M. Cutler, Edward L. Glaeser \& Jacob L. Vigdor, The Rise and Decline of the American Ghetto, 107 J. Political ECON. 455, $465-66$ (1999) ("To a great extent, the modern spatial distribution of races in American cities was established by 1940.").

30. Cashin, supra note 27 , at 596 ("Currently, with each passing decade, we as a nation are becoming increasingly segregated by income.").

31. Melvin L. Oliver \& Thomas M. Shapiro, Black Wealth/White Wealth: A New Perspective on Racial InEQuality 67-90 (1995).

32. See, e.g., Press Release, Woodstock Institute, Report Finds Dual Market in Refinance Loans: Subprime Lenders Dominate Lending in Minority Neighborhoods (Nov. 15, 1999) (summarizing report analyzing home refinance lending in the Chicago area and documenting the extreme segmentation of mortgage markets by race and neighborhood) available at http://woodstockinst.org/document/2stepsback.html; Assocs. Home Equity Servs., lnc. v. Troup, 778 A.2d 529, 536 n.2 (N.J. Super. Ct. App. Div. 2001) (citing the findings of Elvin Wyly that HMDA data support the existence of a "dual housing finance market ... in New Jersey for the refinance and home repair loans" with "urban areas of heavy minority concentration [] being disproportionately serviced by subprime lenders").

33. Wyly et al., supra note 25 , at 657 . 
foreclosure rates, the spiral of neighborhood disinvestment intensifies and the demand for subprime loans increases. ${ }^{34}$

This Part will examine the underpinnings of today's racially and geographically concentrated subprime lending. First, I trace the development of a two-tiered, segregated banking system created by the explicit bank "redlining" of black neighborhoods in the early part of the twentieth century. Second, I examine how federally supported real estate appraisal and land-use policies worked in conjunction to create and maintain a standardized scale of property value that purposefully placed black communities at the lowest end of the value spectrum. Third, I discuss the passage of the FHA as an effort to reduce residential segregation in America. The insufficiency of traditional housing discrimination doctrine under the FHA and the recent doctrines developed to better combat the discriminatory effects of racially concentrated subprime lending are discussed infra in Part III.

\section{A. Redlining in the Banking Industry}

Lack of access to traditional sources of home purchase finance played an integral role in the maintenance of de facto racial segregation in the early twentieth century. ${ }^{35}$ "Redlining" is the "practice of denying the extension of credit to specific geographic areas due to the income, race, or ethnicity of its residents." ${ }^{36}$ In the first half of the twentieth century, mainstream banks largely redlined black neighborhoods. ${ }^{37}$ Denied access to mainstream lenders, blacks were forced to borrow from black-owned financial institutions or informal lenders who charged above-market rates. ${ }^{38}$

The term "redlining" comes from the color-coded maps that the Home Owners Loan Corporation (HOLC), a federally operated lender that offered low-interest loans during the Great Depression, used to determine the areas in which it would lend. ${ }^{39}$ The HOLC coded as red the lowest-quality,

34. This sort of "feedback loop" is common to many theories of discrimination. Daria Roithmayr tells a similar "market failure story" about persistent racial disparity in law school admissions rates. Shc uses the antitrust theories of market lock-in and path dependence to show how a racial group's early monopoly can become "self-reinforcing and ultimately locked in." See Daria Roithmayr, Locked in Inequality: The Persistence of Discrimination, 9 MiCH. J. RACE \& L. 31, 33 (2003). Gunnar Myrdal described this phenomenon as the "vicious circle" or the "principle of cumulation" by which cause and effect mutually reinforce each other. Gunnar Myrdal, An American Dilemma: The Negro Problem and Modern Democracy 75 (1942). For example, Myrdal explains, "an increase in white prejudice has the effect of pressing down still further the Negro plane of living, which again will increase prejudice, and so on, by way of mutual interaction between the two variables, ad infinitum." Id. at 1066

35. For a summary of the history of mortgage discrimination and redlining, see IMMERGLUCK, supra note 10 , at $87-108$.

36. United Cos. Lending Corp. v. Sargeant, 20 F. Supp. 2d 192, 203 n.5 (D. Mass. 1998).

37. IMMERGLUCK, supra note 10 , at 87 .

38. Id. at 88 .

39. MASSEY \& DENTON, supra note 28 , at 51 . 
highest-risk neighborhoods and largely refused to lend in such areas. ${ }^{40}$ Black areas were consistently coded red. ${ }^{41}$ Commentators have noted that the HOLC's color-coded maps "lent the power, prestige and support of the federal government to the systematic practice of racial discrimination in housing.",42

Scholars disagree about the extent to which the HOLC maps led to redlining by private lenders. ${ }^{43}$ However, even those who question such a causal relationship admit that private lenders in redlined black neighborhoods charged higher interest rates. ${ }^{44}$ Regardless of the extent of the federal government's role in "initiat[ing] and institutionalizing" redlining, ${ }^{45}$ white borrowers' access to residential mortgage loans during the 1930 s and 1940s was far superior to black borrowers' access.

In addition to discriminatory motives that may have led lenders to redline black neighborhoods, economists have also posited economic explanations for redlining. Stiglitz and Weiss argue that lack of creditworthiness information can lead to economically rational redlining: if lenders are unable to distinguish a good credit risk from a bad one, but know that loans in a particular area are more risky, they have an incentive to avoid the area altogether. ${ }^{46}$ Lang and Nakamura, on the other hand, propose a theory of economically rational redlining that follows from lenders' historical refusal to lend in certain neighborhoods. ${ }^{47}$ According to the theory, reductions in residential lending in a given area are self-perpetuating. Because appraisals are based upon past home sales, in areas where such transactions are few, lenders will have greater uncertainty as to the value of any particular property. ${ }^{48}$ Lenders will seek compensation for this uncertainty by requiring higher down payments or charging higher interest rates. ${ }^{49}$ The higher costs of loans will result in fewer loans being made in that area. ${ }^{50}$

\footnotetext{
40. Id.

41. Id. at 52 .

42. Id.

43. Amy Hillier, Who Received Home Loans? Home Owners Loan Corporation Lending and Discrimination in Philadelphia in the 1930s, 2 J. PLAN. Hist. 3,4 (2003) ("Recent research challenges this causal relationship between HOLC maps and disinvestment.").

44. Id. (" $[\mathrm{L}]$ enders continued to make loans in areas colored red (although the interest rates were higher).").

45. MASSEY \& DENTON, supra note 28 , at 51.

46. Gary A. Dymski, Discrimination in the Credit and Housing Markets: Findings and Challenges, in HANDBOoK ON Discrimination (William Rogers ed., forthcoming).

47. William W. Lang \& Leonard 1. Nakamura, A Model of Redlining, 33 J. URBan Econ. 223

48. Id.

49. Id.

50. Reynold Nesiba, Racial Discrimination in Residential Lending Markets: Why Empirical Researchers Always See It and Economic Theorists Never Do, 30 J. Econ. 1ssues 51, 66 (1996) (summarizing Lang and Nakamura's theory of redlining).
} (1993). 
Moreover, if major lenders redline a neighborhood, smaller lenders may be unable to capture the market share that the larger lenders have left behind. ${ }^{51}$ If smaller lenders cannot stop the decline in home values caused by the larger lenders' redlining, smaller lenders have strong economic incentives to follow the other lenders' lead by avoiding the area. ${ }^{52}$ Although redlining originated in racist attitudes codified onto color-coded maps, it has been perpetuated through economically rational lending practices that have harmful, self-reinforcing effects.

\section{B. Constructing Value: Real Estate Appraisal}

Because real property is inherently unique, its value must be translated onto a standardized scale for it to become fungible like other property forms. Moreover, because real property typically secures mortgagc loans for several decades, lenders consider both a property's current value and its value over the life of the loan. Standardized real estate appraisal addresses each of these demands. As one court has noted, "[r]eal estate appraisal is not an exact science." 53 But, in fact, modern real estate appraisal methods cvolved from pseudo-scientific theories that viewed "infiltration" of racial minorities as causing property value declines. ${ }^{54}$ Developed at a time when racial segrcgation was state sponsored, professionalized real estate appraisal has perpetuated and reinforced initial inputs of high and low value originally based on a neighborhood's racial composition. Thus, real estate appraisal and its attendant land-use controls ${ }^{55}$ form a link between race and space by bringing past discrimination into the contemporary calculus of loan approval and pricing.

\section{Development of Real Estate Appraisal: The Uniformity Principle and Privileged Uses}

Whereas exclusion of undesirable uses is the animating principle of real estate valuation and land-use policy in the United States, ${ }^{56}$ the paradigm of value is the white, suburban, middle-class, single-family

51. Id. at 72 .

52. Id.

53. Latimore v. Citibank Fed. Sav. Bank, 151 F.3d 712, 715 (7th Cir. 1998).

54. Fed. Hous. admin., Underwriting Manual: Underwriting and Valuation Procedure Under Title II of the National Housing Act Part 1, \ 323(3) (1936) ("The infiltration of inharmonious racial groups will produce the same effects as those which follow the introduction of nonconforming land uses which tend to lower the levels of land values and to lessen the desirability of residential areas.") [hereinafter FHA UNDERWRITING MANUAL] .

55. Land-use controls aimed at preservation of a racialized paradigm of value further entrenched a racially segregated geography. David Dante Troutt, Ghettoes Made Easy: The Metamarket/Antimarket Dichotomy and the Legal Challenges of Inner-City Economic Development, 35 HARv. C.R.-C.L. L. REv. 427, 434 (2000).

56. Id. at $\mathbf{4 3 5}$ ("The conceptual premise for land use planning in general, and zoning in particular, is the segregation of desirable from less desirable uses."). 
home. ${ }^{57}$ As real estate appraisal became professionalized in the $1930 \mathrm{~s}$, the reigning consensus was that homeowners should be separated by both class and race. ${ }^{58}$ This consensus was premised on the belief that the influx of certain races into an area would cause property values there to decline. ${ }^{59}$ In his influential 1933 book One Hundred Years of Land Values in Chicago, Homer Hoyt ranked various races and nationalities "with respect to their beneficial effect upon land values." Germans, Scotch, lrish, [and] Scandinavians" exerted the most favorable effects on property values and were ranked first, while "Negroes [and] Mexicans" exerted "the most detrimental effect" and were listed last. ${ }^{61}$

The notion that racial integration caused property value declines can be seen as a natural, albeit racist, component of the functionalist "uniformity principle" on which real estate appraisal is premised. ${ }^{62}$ Appraisal of one property by comparison of it to similar properties within a bounded geographic area assumes that properties of similar character and use will be clustered together. ${ }^{63}$ Formalized real estate appraisal thus disfavors an industrial plant located in a residential neighborhood because the plant lacks comparables within the area against which its value may be assessed. In addition, the existence of multiple, conflicting land uses would make the comparison area's future prospects difficult to forecast. Accordingly, given the appraisal profession's racialized notions of value, all-white neighborhoods were rewarded for their uniformity, while

57. See id. at 437. Troutt argues that implicit in the U.S. Supreme Court's ratification of zoning ordinances to segregate land uses in Village of Euclid v. Ambler Realty Co., 272 U.S. 365 (1926), is a preference for a middle-class ideal of detached single-family residences. Id. The Supreme Court articulated the prototypical image of such an ideal in Village of Belle Terre v. Boraas: "A quiet place where yards are wide, people few, and motor vehicles restricted are legitimate guidelines in a land-use project addressed to family needs." 416 U.S. 1, 9 (1974).

58. Guy Stuart, Discriminating Risk: The U.S. Mortgage Lending Industry in The TWentieth Century 33-34 (2003).

59. Homer Hoyt, One Hundred Years of Land Values in Chicago 314 (1933) ("[C]ertain racial and national groups, because of their lower economic status and their lower standards of living pay less rent themselves and cause a greater physical deterioration of the property than groups higher in the social and economic scale.").

60. Id.

61. Id. at 316. Moreover, according to Hoyt, whereas European immigrants assimilated into the general whitc population as they rose in social class, the segregation of blacks and "Mexicans" was permanent. Id at 314 ("Except in the case of negroes and Mexicans ... racial and national barriers disappear when the individuals in the foreign nationality groups rise in the economic scale.").

62. The 1936 FHA Underwriting Manual considered the "principle of uniformity upon which the comparative method of land valuation is based" to arise from the fact that "it is common to find residential communities of considerable area in which the characteristics of the individual properties are substantially alike" and similarly affected by influenees from outside the neighborhood. FHA UNDERWRiting MANUAL, supra note 54, at Part I, ๆ 337(2).

63. Indeed, the 1936 FHA Underwriting Manual states, "The best type of residential district is one in which the values of individual properties vary within comparatively narrow limits ... Such a district is characterized by uniformity." Id. at Part $1, \uparrow 316$. 
integrated neighborhoods were downgraded for their heterogeneity. ${ }^{64}$ Though racial considerations have been excised from the appraisal process, real estate appraisal continues to privilege homogeneity of use within geographical boundaries. $^{65}$

Moreover, the effects of low appraisals are self-reinforcing. A single under-appraisal devalues property in the same neighborhood when that valuation is used as a comparable for a subsequent appraisal. ${ }^{66}$ Under-appraisals also make it more difficult for borrowers in the neighborhood to obtain home purchase financing, and, as lenders make fewer loans in a neighborhood, the relative weight of each appraisal is increased. ${ }^{67}$

Direct challenges under the FHA to the discriminatory impact of real estate appraisal have met limited success. In 1976, the Department of Justice obtained a settlement with real estate appraisers that required them to declare, inter alia, that racial, ethnic, or religious homogeneity was an improper consideration in real estate valuation and that racial or ethnic factors were unreliable predictors of value trends. ${ }^{68}$ However, private plaintiffs have been less successful in housing discrimination challenges to real estate appraisal methods. In Hanson $v$. Veteran's Administration, ${ }^{69}$ the plaintiffs alleged that "the value of their property was discriminatorily adjusted downward" 70 by Veterans Administration (VA) appraisers on account of its location. The plaintiffs showed that VA appraisal guidelines had, until 1977, employed the "principle of conformity."71 Adhering to such a principle, the VA appraisers allegedly devalued property in neighborhoods that were not homogeneous, and categorized different ethnic groups by their relative detrimental effect upon real estate values in the neighborhoods they "infiltrated." 72 Nevertheless, the VA presented

64. See Hanson v. Veteran's Admin., 800 F.2d 1381, 1387-89 (5th Cir. 1986) ("“A] widely used appraisal text, The Appraisal of Real Estate, instructed appraisers until 1977 that the value of the property being appraised should be adjusted downward if the ethnic composition of the neighborhood to which it belonged was not homogeneous.").

65. STUART, supra note 58, at 34-35.

66. Hanson, 800 F.2d 1389 (recounting expert testimony that underappraisals could "effectively place a 'lid' on the entire [neighborhood] market" if an underappraisal led to a lower sales price that was subsequently used as a comparable to appraise another property in the area).

67. IMMERGLUCK, supra note 10, at 105; see also Lang \& Nakamura, supra note 47, at 223-34; supra note 47-50 and accompanying text. One study, using national data, showed that housing units lose approximately $46 \%$ of their value if the neighborhood's black population increases from less than $10 \%$ to greater than $60 \%$. David R. Harris, "Property Values Drop When Blacks Move in, Because...": Racial and Socioeconomic Determinants of Neighborhood Desirability, 64 AM. Soc. REv. 461, 471 (1999).

68. United States v. Am. Inst. of Real Estate Appraisers, 442 F. Supp. 1072, 1077 (N.D. Ill. 1977).

69. 800 F.2d 1381 .

70. Id. at 1384 .

71. Id. at 1387 .

72. Id. 
nondiscriminatory reasons for the low appraisals that the district court found plausible, and the appellate court found no clear error. ${ }^{73}$

\section{Federal Adoption of Real Estate Appraisal Methods: The Reinforcement of Segregation}

In the 1930s, the federal government relied on the quasi-scientific urban sociology espoused by proponents of formalized real estate appraisal to create a standardized scale of real estate value that was essential to the Federal Housing Administration's mortgage insurance program. ${ }^{74}$ Just as HOLC maps helped institutionalize redlining during the Great Depression, ${ }^{75}$ the work of Federal Housing Administration appraisers (or "valuators") ${ }^{76}$ channeled mortgage insurance to white, suburban areas and away from black, inner-city neighborhoods. ${ }^{77}$

The Federal Housing Administration used its Underwriting Manual to determine which residential mortgages to insure. ${ }^{78}$ The Manual "laid the ground work for today's appraisal theory and practices."79 The Manual generalized that "the central downtown core of the city ... can usually be outlined and considered ... ineligible" for mortgage insurance. ${ }^{80}$ This exclusion of downtown areas had significant racial and class implications. ${ }^{81}$ However, early FHA Manuals reveal an even more pronounced racial bias. In prescribing a formula for the rating of a property's location, the 1936 Manual gave $20 \%$ weight to a neighborhood's "Protection from Adverse Influences." 82 Chief among such "adverse influences" was the potential for a change in the "racial occupancy" of the neighborhood. ${ }^{83}$ The 1936 Manual required appraisers to give higher values to neighborhoods that had protection from the "infiltration of . . . inharmonious racial groups." ${ }^{\text {" S4 }}$ Such protections included zoning ordinances, ${ }^{85}$ deed restrictions, ${ }^{86}$ and even

\footnotetext{
73. Id. at $1388,1390$.

74. STUART, supra note 58 , at $45-47$; see also IMMERGLUCK, supra note 10 , at 91 .

75. See MASSEY \& DENTON, supra note 28 at 51 ; supra notes $39-45$ and accompanying text.

76. FHA UNDERWRITING MaNUAL, supra note 54, at Part I, $\uparrow 121$.

77. IMMERGLUCK, supra note 10 , at 95 ("[T]he major federal housing program made housing much more affordable primarily to those white buyers buying homes in racially pure and mostly suburban communities."); STUART, supra note 58, at 54.

78. FHA UNDERWRITING MANUAL, supra note 54 at Part I, $\uparrow 13 \mathrm{I}$.

79. STUART, supra note 58 , at 47 .

80. FHA Underwriting Manual, supra note 54, at Part II, $\lceil 208$.

81. See 1 I4 CONG. REC. 3421 (1968) ("Eighty percent of the nonwhite population of metropolitan areas in 1967 lived in central cities.").

82. FHA UNDER Writing ManUal, supra note 54, at Part II, $\mid 204$

83. Id. at Part II, $\lceil 233$.

84. Id. at Part II, $\ 229$.

85. Id. at Part II, 1227.

86. Id. at Part II, I 228. The Federal Housing Administration encouraged the use of restrictive covenants to prevent properties from being sold to blacks, IMMERGLUCK, supra note 10, at 94, until the Supreme Court declared this type of covenant unconstitutional in 1948. See generally Shelley v.
} 
physical barriers to "infiltration" such as "hills and ravines" and "highspeed traffic arter[ies]." $" 87$

The preference for insulated white neighborhoods was so pronounced that, in the Administration's eyes, "properties owned by blacks did not even warrant a rating, because there was nothing to rate them against." 88 By exhibiting a bias against the central city and racially integrated neighborhoods, and by steering homeownership assistance efforts to white suburban communities, ${ }^{89}$ the Federal Housing Administration ensured the self-fulfilling prophecies of its own biased measures of value.

The appraiser's functional need for discrete areas from which to draw comparables resulted in the overlaying of an invisible grid of value-laden boundaries onto the physical landscape of urban America. ${ }^{90}$ This invisible grid is self-reinforcing, supporting a real estate valuation system that has increasingly driven land-use policy toward conformance with the principle that like uses should be clustered and unlike uses should be excluded. ${ }^{91}$ Within this paradigm of privileged and unprivileged uses, racial value judgments were abstracted into a purportedly objective system of rcal estate appraisal that, in fact, embodies "a certain set of values that tend to advantage one group of peoplc over another." $"$

\section{The Fair Housing Act}

In 1968, just six days after the assassination of Martin Luther King, Jr., and less than two months after the presidentially appointed Kerner Commission concluded, "[o]ur Nation is moving toward two societies, one black, one white-separate and unequal, ${ }^{, 93}$ President Johnson signed the FHA $^{94}$ into law. The legislation sought to eliminate the effects of statesanctioned racial segregation and "provide, within constitutional

\footnotetext{
Kraemer, 334 U.S. 1 (1948) (holding that judicial enforcement of racially restrictive covenants violates the Fourteenth Amendment).

87. Id. at Part II, \ 229.

88. STUART, supra note 58 , at 55 .

89. IMMERGLUCK, supra note 10, at 95.

90. STUART, supra note 58, at 35. The 1936 FHA Manual charges each Insuring Office to maintain a record of "Established Ratings of Location" and suggests a "combination of cards and maps" be used: "First the neighborhoods are outlined on maps. The bettcr locations are rated by the use of the Rating of Location grid." FHA Underwriting MANUaL, supra note 54, at Part II, ๆ 209. Then "descriptive materials should be placed on a card so that the basis of the rating may be recorded." Id. The records were maintained by the chief valuator and were available for use whenever a subsequent request for mortgage insurance on a property within that area was made. Id.

91. STUART, supra note 58 , at 35 .

92. Id. at 30 .

93. The Nat'l Advisory Comm'n on Civil Disorders, Report of The National Advisory Commission on Civil Disorders 1 (1968); see also MASSEy \& Denton, supra note 28, at 3-4, 19394.

94. Fair Housing Act, Pub. L. No. 90-284, Title VIII, 82 Stat. 81 (1968) (codified as amended at 42 U.S.C. $\$ \S 3601$ et seq. (2000))
} 
limitations, for fair housing throughout the United States." 95 Senator Mondale, author of much of the FHA, stated that the law was designed to achieve "truly integrated and balanced living patterns." ${ }^{.96}$ With such clear congressional intent, courts have consistently interpreted the statute expansively. ${ }^{97}$ Courts have attributed to Congress an intent to "alter the whole character of the housing market." ${ }^{98}$ In addition, the FHA's principal purpose has been described as promoting "open, integrated residential housing patterns." 99 The FHA has been used not only to challenge, ex post, individual instances of housing discrimination, but also to ensure that proposed housing practices or policies affirmatively advance the goal of integrated housing. ${ }^{100}$

\section{The FHA's Prohibitions}

Under Section 804 of the FHA, it is unlawful:

(a) To refuse to sell or rent after the making of a bona fide offer, or to refuse to negotiate for the sale or rental of, or otherwise make unavailable or deny, a dwelling to any person because of race, color, religion, sex, familial status, or national origin.

(b) To discriminate against any person in the terms, conditions, or privileges of sale or rental of a dwelling, or in the provision of services or facilities in connection therewith, because of race, color, religion, sex, familial status, or national origin. ${ }^{101}$

Section 805 of the FHA applies only to banks or other firms "whose business consists in whole or in part in the making of commercial real estate loans." 102 It is illegal for such actors to "deny a loan or other financial assistance" for the purpose of "purchasing, constructing, improving, repairing, or maintaining a dwelling" on the basis of the protected categories of race, color, religion, sex or national origin. ${ }^{103}$ Section 805 specifically addresses "the amount, interest rate, duration, or other

\footnotetext{
95. 42 U.S.C. $\$ 3601$.

96. 114 CoNG. REC. 3422 (1968) (statement of Sen. Mondale).

97. See, e.g., Trafficante v. Metro. Life Ins. Co., 409 U.S. 205, 209-11 (1972) (holding that persons who lost the social benefits of living in an integrated community were "aggrieved" persons under the FHA).

98. Mayers v. Ridley, 465 F.2d 630, 652 (D.C. Cir. 1972).

99. Huntington Branch, NAACP v. Town of Huntington, 844 F.2d 926, 937 (2d Cir. 1988) (quoting Otero v. N.Y. Hous. Auth., 484 F.2d 1122, 1134 (2d Cir. 1973)).

100. Such affirmative duties are imposed on HUD by 42 U.S.C. $\S 3608(e)(5)$. See, e.g., NAACP v. Sec'y of HUD, 817 F.2d 149 (1st Cir. 1987) ("Title VIIl imposes upon HUD an obligation to do more than simply refrain from discriminating (and from purposely aiding discrimination by others)."). Such affirmative duties do not extend to private actors.

101. 42 U.S.C. $\S \S 3604(a)-(b)$ (1968).

102. 42 U.S.C. $\$ 3605$.

103. Id.
} 
terms or conditions" of home loans or financial assistance. ${ }^{104}$ Therefore, charging higher interest rates on the basis of race exposes a lender to liability under the FHA. Although these sections apply to distinct aspects of fair housing provision, courts interpret the discrimination element in each section similarly. Specifically, the courts have broadly interpreted the phrase "otherwise make unavailable or deny." 105 As will be discussed infra in Part III, the expansive interpretation of the FHA supports the development of fair housing doctrine suited to address the new exploitation paradigm of housing discrimination.

\section{The FHA and Redlining}

Although passed to end de facto segregation, the FHA does not explicitly outlaw redlining. Both the courts and HUD regulations, however, have interpreted the FHA to prohibit such practices. ${ }^{106}$ Because one's geography does not make one a member of a protected class, some courts have resorted to indirect logic in reasoning that redlining violates the FHA. In Laufman v. Oakley Building and Loan, ${ }^{107}$ for example, the district court held that redlining increases segregation in violation of the FHA. According to the court, redlining makes whites, already reluctant to fill housing openings in black or integrated neighborhoods, even less likely to occupy available homes in minority areas if residence hinges on paying higher rates for loans or insurance or being denied such financial assistance altogether. ${ }^{108}$

The court's analysis may be descriptively correct. However, such analysis ignores the underlying manner in which redlining is discriminatory: discrimination based on geography necessarily leads to racially disparate outcomes. Given the persistent severity of de facto racial segregation in America, decisions by insurers or lenders made according to geography should be closely scrutinized. When such decisions cannot be justified by legitimate economics (such as higher risk of loss or claim volume) and closely track the spatial dimension of racial composition, such decisions

104. Id; see also Harper v. Union Sav. Ass'n, 429 F. Supp. 1254, 1257, 1259 (N.D. Ohio 1977) (commenting that the phrase "terms and conditions" should be given the "broadest possible construction").

105. See, e.g., Nat'l Fair Hous. Alliance v. Prudential lns. Co. of Am., 208 F. Supp. 2d 46, 56 (D.D.C. 2002) ("Plaintiffs persuasively argue that ... the broad, general language [of the FHA]reflected in phrases such as 'otherwise make unavailable or deny'-was intended to be flexible enough to cover multiple types of housing-related transactions.").

106. See, e.g., NAACP v. Am. Family Mut. Ins., 978 F.2d 287, 291 (7th Cir. 1992) (holding that insurance redlining violates the FHA so long as plaintiffs can establish that the insurer drew lines "according to race rather than actuarial calculations"); see also Nationwide Mut. Ins. Co. v. Cisneros, 52 F.3d 1351 (6th Cir. 1995) (holding that HUD regulation prohibiting property insurance redlining was a reasonable interpretation of FHA).

107. 408 F. Supp. 489, 495-97 (S.D. Ohio 1976).

108. Id. 
should be presumed discriminatory under a disparate impact approach, a strategy discussed in greater detail in Part III.

\section{II \\ SubPrime Lending in the 1990s: Capital Markets, the Inner City, AND MARKET FAILURE}

Residential real estate lending exploded throughout the $1990 \mathrm{~s},{ }^{109}$ and the percentage of the overall market constituted by subprime real estate loans grew at an even greater rate. ${ }^{110}$ In 2001 the Wall Street Journal reported a tripling in the number of outstanding subprime mortgage loans since $1995,{ }^{111}$ and HUD has estimated that lenders originated $\$ 160$ billion worth of subprime loans in 1999 , compared to $\$ 35$ billion in $1994 .{ }^{112}$ This explosive growth can be attributed to deep structural changes in mortgage markets in the past quarter-century, including increases in available capital made possible by securitization, the increase in risk-based pricing facilitated by technological advances, and a steady trend in banking industry deregulation. Although the structural shifts responsible for the growth of subprime lending have increased access to residential lending capital, such shifts have also led to the concentration of subprime loans in formerly redlined inner-city neighborhoods.

\section{A. Structural Shifts in the Mortgage Lending Industry}

\section{Securitization}

Perhaps the most significant structural change in mortgage markets in the past twenty years is the linkage of global capital and residential real estate loans. This linkage was made possible by securitization-the pooling of loans to form securities which are subsequently sold into a secondary market. ${ }^{113}$ Securitization dramatically increased the amount of capital

I09. From 1994 to 1999 , total annual home-loan originations grew $60 \%$, from $\$ 773$ billion to $\$ 1.275$ trillion. HUD-TREASURY REPORT, supra note 14, at 29. Even more pronounced was the growth of lending to lower- and middle-income borrowers, which saw an $80 \%$ increasc between 1993 and 1999. Id. at 24.

110. Subprime loans as a percentage of total originations grew from $4.5 \%$ to $12.5 \%$ from 1994 to 1999. Id. at 29. One source reported that the subprime share of the overall mortgage markct tripled between 1994 and 1997-from under 5\% to 15\%. Howard Lax et al., Subprime Lending: An Investigation of Economic Efficiency, 15 Housing POL'y DEBate 533, 534 n.3 (2004).

111. Carrick Mollenkamp et al., Banker Beware: As Economy Slows, 'Subprime' Lending Looks Even Riskier, Wall St. J., Aug. 16, 2001, at A1.

112. Kenneth Temkin et al., U.S. Dep't of Hous. \& Urban Dev., Subprime Markets, the ROLE OF GSEs, AND RISK-BASED PRICING vii (2002), available at http://www.huduser.org/publications/hsgfin/subprime.html.

113. Securitization works as follows: A mortgage loan originator transfers a pool of loans to a "special purpose corporation, trust, or other legally separate entity," known as a special purposc vehicle (SPV). Steven L. Schwarcz, The Alchemy of Asset Securitization, 1 STAN. J. L. Bus. \& Fin. 133, 135 (1994). For the securities to be acceptable on the market, the sale from the originator to the SPV must be a "true sale" so that the originator reduces the amount of liability attached to the loans when 
available to mortgage lenders and was the most significant cause of subprime lending's rapid growth. ${ }^{114}$

The sale of mortgages into a secondary mortgage market maximizes the amount of available residential lending capital by permitting lenders to use the proceeds from such sales to make additional loans. The federal government first created a secondary market for mortgages in the 1930 s to combat the Depression-era shortage of residential loan funds. ${ }^{115}$ In the 1970s, Government Sponsored Entities (GSEs) Fannie Mae and Freddie Mac created and sold securities backed by federally insured home loans to further increase the aggregate available residential lending capital. ${ }^{16}$ Securitization in the private sector became possible in the 1980 s when ratings agencies began to rate privately issued mortgage-backed securities, giving investors confidence in securities not backed by the federal government. ${ }^{117}$ From 1984 to 1998 , the percentage of outstanding securitized residential loans grew from $23 \%$ to $52 \%$ of all outstanding residential loans. ${ }^{18}$ Through private securitization the residential mortgage market, along with credit markets more generally, became integrated with the capital markets of Wall Street. ${ }^{119}$

\section{New Players: Mortgage Brokers and Other Non-Deposit Lenders}

Traditionally, subprime lending was dominated by specialized consumer-finance companies that specialized in lending to those with impaired credit. ${ }^{120}$ Through the 1990 s, however, big subprime players were increasingly swept up by even bigger mainstream banks. ${ }^{121}$ The most high profile

transferred. Id. (A "true sale" is a sale that, under bankruptcy law, removes the receivables from the seller's bankruptcy estate.) Id. The SPV then creates securities based on the income stream from the loans. Id. Securitization was made possible by technological advances allowing investment banks to assess and minimize risk associated with a pool of loans. Id. A vigorous debate is now underway as to whether securitization provides holders of mortgage-backed securities too much insulation from the predatory practices of the originators of the securitized loans.

114. City of Oakland v. Am. Fin. Servs. Ass'n, 104 P.3d 813, 833 (Cal. 2005) (George, C.J., dissenting) ("The bulk sale of mortgage loans on the secondary market is the primary profit incentive for subprime mortgage lenders."). Investors purchased more than $\$ 60$ billion of subprime mortgagebacked securities in 1997, compared to a mere \$10 billion in 1991. HUD-TREASURY REPORT, supra note 14 , at 41 .

115. See, e.g., Stuart, supra note 58, at 25.

116. Kurt Eggert, Held Up in Due Course: Predatory Lending, Securitization, and the Holder in Due Course Doctrine, 35 Creighton L. REv. 503, 537 (2002). With the federal government's full credit behind them, these securities were seen as virtually "risk free." Id. Furthermore, GSEs only purchase loans that meet strict underwriting requirements, minimizing the risk associated with the securitized pool of loans. Id.

117. Id.

118. Id. at 538 .

119. See Kathleen W. Johnson, Consumer Loan Securitization, in The Impact of Public Policy on Consumer Credit 301 (Thomas A. Durkin \& Michael E. Staten, eds. 2002); Eggert, supra note 116 , at 536 .

120. Mollenkamp et al., supra note 111 .

121. Id. 
of such deals was Citigroup's acquisition of subprime giant The Associates in $2000 .^{122}$ Although they profited from the subprime sector, mainstream banks largely maintained separation between their subprime and prime divisions. ${ }^{123}$

Securitization also made possible the increased market share of nondeposit institutions, namely mortgage brokers, who typically originate loans on behalf of wholesale lenders which in turn sell the mortgages into the secondary market. ${ }^{24}$ The transition of mortgage origination from federally insured deposit institutions, which hold mortgages in their own asset portfolios, to mortgage brokers and wholesale lenders, which sell the loans into the secondary market, has rearranged incentives in the industry. ${ }^{125}$ Mortgage brokers have less incentive to offer fairly priced loans because they do not directly bear the risk of default. ${ }^{126}$ Rather, mortgage brokers, who originated close to $60 \%$ of mortgage loans in 2002 , are motivated to maximize their commissions by originating the largest loan possible. ${ }^{127}$

Further, yield-spread premiums, one of the primary forms of mortgage broker compensation, ${ }^{128}$ reward mortgage brokers for steering borrowers to overpriced loans. ${ }^{129}$ Yield-spread premiums are payments from wholesale lenders to mortgage brokers amounting to a percentage of the difference between the interest rate of the newly originated loan and the lender's published par rate. ${ }^{130}$ Such payments give mortgage brokers an incentive to originate loans with high interest rates. ${ }^{131}$ Although, theoretically, such payments could help cash-strapped borrowers spread the up-front costs of loan origination over the life of the loan, empirical data show that mortgage brokers typically retain $75 \%$ of yield-spread premiums as

122. Wyly et al., supra note 25 , at 623 . Citibank promptly paid $\$ 215$ million to settle predatory lending charges brought by the Federal Trade Commission. Id. at $625 \mathrm{n} .1$.

123. Id. at 624; Kathleen C. Engel \& Patricia A. McCoy, A Tale of Three Markets: The Law and Economics of Predatory Lending, 80 TEX. L. REV. 1255, 1296 (2002).

124. Eggert, supra note 116 , at 553.

125. Id.

126. Id.

127. Id. Because a number of states require only minimal capitalization for brokers, many such brokers may be judgment-proof. Id. at 556 .

128. Howell Jackson, Predatory Mortgage Lending Practices: Abusive Use of Yield Spread Premiums, Testimony at U.S. Senate Committee on Banking, Housing, and Urban Affairs, Washington, D.C., (Jan. 8, 2002), available at http://banking.senate.gov/02_01 hrg/010802/jackson.htm\#N_7.

129. A subprime loan is "overpriced" if the interest rate and origination fees paid are incommensurate with the additional risk posed by the borrower.

130. Taiesha L. Cantwell, Yield-Spread Premiums: Who's Working for the Borrower? HUD's Erroneous Regulation and Its Bar on Plaintiffs, 21 LAW \& INEQ. 367, 370-71 (2003); see also Engel \& McCoy, supra note 123, at 1264; Hud-TREASURY RePORT, supra note 14, at 80 . "The term 'par rate' refers to the rate offered to the broker (through the lender's price sheets) at which the lender will fund $100 \%$ of the loan with no premium or discounts to the broker." HUD-TREASURY REPORT, supra note 15 at 40 .

131. Engel \& MeCoy, supra note 123, at 1264. 
compensation. ${ }^{132}$ Moreover, brokers have no obligation to disclose yieldspread premiums to borrowers, ${ }^{133}$ and evidence suggests that racial minorities pay significantly more in yield-spread premiums than do white borrowers. ${ }^{134}$

\section{Legislative Deregulation of the Mortgage Lending Industry}

The decades-long trend of bank deregulation ${ }^{135}$ culminated with the passage of the Gramm-Leach-Bliley Act ${ }^{136}$ in 1999, permitting financial service providers to merge with insurers. ${ }^{137}$ The trend began in 1980 when Congress preempted state usury ceilings with the Depository Institutions Deregulation and Monetary Control Act of 1980 (DIDMCA). ${ }^{138}$ Effectively a legislative concession to the Savings and Loan (S\&L) industry, the law helped the industry stay competitive with nonfederally chartered banks where consumers received higher rates of return. ${ }^{139}$ With this law, Congress enabled the S\&Ls to recoup the higher interest rates they were paying by allowing them to preempt state usury laws for loans to consumers secured by a first lien on their homes. ${ }^{140}$

Deregulation continued with the Alternative Mortgage Transaction Parity Act of 1982 (AMTPA), ${ }^{141}$ extending federal mortgage lending

\footnotetext{
132. Jackson, supra note 128.

133. Engel \& McCoy, supra note 123, at 1264.

134. Jackson, supra note 128.
}

135. IMMERGLUCK, supra note 10, at 266 ("In the last twenty-five years, there has been a deliberate and organized movement, aggressively promoted by the financial services sector, Congress, and many federal regulators, to reduce the public-sector oversight of the financial services sector."). Immergluck argues that the deregulationist stance ignores the fact that the federal government is largely responsible for today's "robust" financial services market and much of the most important "financial infrastructure" of U.S. mortgage markets. Id. at 266-67.

136. Pub. L. No. 106-102, 113 Stat. 1338 (1999) (codified as amended in scattered sections of 15 U.S.C. and 12 U.S.C.).

137. Matthew Lee, Community Reinvestment in a Globalizing World: To Hold Banks Accountable, from The Bronx to Buenos Aires, Beijing, and Basel, in ORganlzing AcCEss to CAPITAL 135, I44-45 (Gregory D. Squires ed., 2003). The Gramm-Leach-Bliley Act paved the way for Citibank and Travelers Group to merge to form CitiGroup in 2000. Id.

138. Pub. L. No. 96-221, 94 Stat. 132 (codified as amended in scattered sections of 12 U.S.C.).

139. Cathy Lesser Mansfield, The Road to Subprime "HEL " was Paved with Good Congressional Intentions: Usury Deregulation and the Subprime Home Equity Market, 51 S.C. L. REv. 473, 520-32 (2000).

140. As Mansfield notes:

It didn't take long after DIDMCA was adopted for some second mortgage lenders, and for other lenders who had been making high cost consumer loans, to notice that DIDMCA appeared to allow them to charge an unlimited amount of interest provided they took a first lien on the borrower's home.

Id. at 511 . Although the courts have consistently held that the DIDMCA provisions do apply to any first lien, Mansfield contends such an interpretation misreads Congress's goal of promoting home ownership. Id. at 517. After DIDMCA, interest on a used-car loan, for instance, may grossly exceed state usury laws so long as it is sccured by a first lien on the borrower's home. Id. at 517 .

141. Pub. L. No. 97-320, $\S \S 801-807,96$ Stat. I469, 1545-48 (codified as amended at I2 U.S.C. $\S \S 3801-3805(2000))$. 
regulations to most residential loans. This extension paved the way for certain loan products that are commonly challenged as predatory. ${ }^{142}$ The Tax Reform Act of $1986^{143}$ made home mortgage interest the only form of taxdeductible interest, creating incentives for homeowners to tap their existing home equity for a stream of future payments. ${ }^{144}$ Next, the Financial Institutions Reform, Recovery, and Enforccment Act of 1989 (FIRREA) ${ }^{145}$ addressed the costly S\&L failures of the 1980 s and created incentives for S\&Ls to operate as thinly capitalized ${ }^{146}$ mortgage brokers relying on the secondary market for loan funds. ${ }^{147}$ Thus, banking deregulation not only paved the way for subprime lenders to charge high interest rates and fees, but it also prompted lendcrs with skewed incentives to enter the market. ${ }^{148}$

Unsurprisingly, the financial services industry has opposed further regulation or increased liability by arguing that both will increase lenders' costs, thereby limiting the number of loans offered to underserved borrowers. ${ }^{149}$ Consistent with this free-market ideology, consumer protection laws like the Truth in Lending Act (T1LA) ${ }^{150}$ and the Real Estate Settlement Procedures Act of 1974 (RESPA) ${ }^{151}$ mandate disclosure of loan price information so that, in theory, borrowers may "comparison shop" for loans with sufficient and accurate pricing information. ${ }^{152}$ ln practice, however, such mandatory disclosures are often too little, too late. ${ }^{153}$

142. Engel \& McCoy, supra note 123 , at 1275 . The loan products allowed by the AMTPA include adjustable-rate mortgages, mortgages with balloon payments, and non-amortizing mortgages where payments only cover interest but do not pay down the principal. $I d$.

143. Pub. L. No. 99-514, 100 Stat. 2085 (codified as amended at 26 U.S.C. $\$ 1$ et seq. (2000))

144. TEMKIN ET AL., supra note 112, at viii.

145. Pub. L. No. 101-73, 103 Stat. 183 (codified as amended in scattered sections of 12 U.S.C.)

146. "Thinly capitalized" mortgage brokers maintain a relatively small volume of capital as they originate loans for wholesale lenders. Thinly capitalized brokers are more likely to be judgment-proof. Eggert, supra note 116, at 556.

147. John C. Weicher, The Home Equity Lending Industry: Refinancing Mortgages for BORROWERS WITH IMPAIRED CREDIT 43-44 (1997).

148. See supra Part II.A.2.

149. This argument assumes that the mortgage market functions efficiently - an assumption that both empirical and anecdotal evidence undcrmine and that courts have said must be relaxed, if not rejected altogether. See Honorable v. Easy Life Real Estate Sys., 100 F. Supp. 2d 885, 888 (N.D. 111. 2000). The argument has met with varied success in court, as evidenced by the California Supreme Court's acceptance of it. City of Oakland v. Am. Fin. Servs. Ass'n. 104 P.3d 813, 824 (Cal. 2005) ("II]ncreased regulation generally entails additional cost, decreasing further the availability of loan funds to subprime borrowers."). Other courts have flatly rejected it. See, e.g., Honorable, 100 F. Supp. $2 \mathrm{~d}$ at 890 (describing the defendant's argument that imposing civil-rights liability on lenders harms the people the laws were designed to help as an "ancient and disreputable proposition").

150. Pub. L. No. 90-321, 82 Stat. 146 (1968) (codified as amended at 15 U.S.C. $\S \S 1601-1693$ (c) (2000)).

151. Pub. L. No. 93-533, 88 Stat. 1724 (codified as amended at 12 U.S.C. $\$ \S 2601-2617(2000)$ ).

152. See Engel \& McCoy, supra note 123, at 1268 . This regulatory philosophy comports with U.S. law's preference for vigorously enforcing fair competition but treating the results of a bargained-forexchange as presumptively valid.

153. Id. at 1307 
The Home Ownership and Equity Protection Act (HOEPA), ${ }^{154}$ a 1994 amendment to TILA aimed at the harmful effects of predatory lending, applies only to home equity or refinance loans, not open-ended extensions of credit or purchase money mortgages. ${ }^{155}$ The act does not cap interest rates or origination fees, but it does mandate heightened disclosures and prohibit certain loan terms for "high-rate, high-fee" loans. ${ }^{156}$ Lenders may easily evade HOEPA disclosure requirements, however, by styling their loans as open-ended lines of credit or pricing them just below HOEPA's interest rate triggers, which are so high that "most lenders, including predatory lenders, are able to price their loans below [them]." "157 In sum, existing consumer protection laws, which aim at ensuring fair competition through disclosure, have proved ineffective to combat the harmful effects of concentrated subprime lending. ${ }^{158}$

\section{B. Risk-Based Pricing and Subprime Loans}

The prime home mortgage is largely a binary product: either a borrower meets the lender's criteria and is granted a loan at the current interest rate or fails to meet the lender's criteria and is denied. The subprime market's use of differential pricing in the form of interest rates and origination fees tied to risk is a relatively new phenomenon facilitated by technological advances in automated underwriting and credit scoring. ${ }^{159}$ In an efficient market the subprime loan's price compensates the lender for the precise increase in risk associated with extending credit to that subprime borrower. ${ }^{160}$ However, strong empirical evidence suggests many subprime lenders exploit information asymmetries created by lack of price

154. 15 U.S.C. $\S \S 1601$, et. seq.

155. HUD-TREASURY REPORT, supra note 14, at 53. "Purchase money mortgages" are loans used to purchase property, as opposed to "home equity loans" by which a borrower borrows against the equity in a home she already owns

156. Id. HOEPA applies to loans (1) with "an annual percentage rate (APR) of more than 10 percentage points above the yield on Treasury securities of comparable maturities"; or (2) which bear points and fees that exceed the greater of $8 \%$ of the loan amount or $\$ 400$. Id. HOEPA subjects such "high-rate, high fee" loans to restrictions on the use of prepayment penalties, balloon payments, and negative amortization. Id. Negative amortization refers to a loan for which monthly paymcnts are insufficient to cover the interest due, thereby causing the amount of principal to increase over the life of the loan. Engel \& McCoy, supra note 123, at 1263.

157. Engel \& McCoy, supra note 123 , at $1307-08$.

158. A full exposition of the shortcomings of existing consumer protection statutes is beyond the scope of this Comment. For a more complcte discussion, see Engel \& McCoy, supra note 123, at 130509.

159. Peter L. McCorkell, The Impact of Credit Scoring and Automated Underwriting on Credit Availability, in The Impact of Public Policy on Consumer Credit supra note 119, at 210, ("Until 1995, scoring was seldom-if ever-used in mortgage lending.").

160. Alan M. White, Risk-Based Mortgage Pricing: Present and Future Research, 15 Housing POL'Y DEBATE 503 (2004). In an efficient market, risk-based pricing makes credit available to economically disadvantaged borrowers who would otherwise be denied access to credit. This is accomplished by matching a borrower with a loan priced precisely to reflect the borrower's risk. 
transparency and a highly segmented market to overcharge ${ }^{161}$ subprime borrowers. ${ }^{162}$ Empirical data support the conclusion that "the higher rates charged by subprime lenders cannot be fully explained solely as a function of the additional risks they bear." 163 A borrower's willingness to pay, rather than the forces of an efficient market, may drive much subprime pricing.

For decades economists have recognized that the unavailability of accurate market information (and unequal access to what little information exists) prevents credit markets from reaching efficient pricing. Stiglitz and Weiss famously posited that lenders' inability to accurately assess the credit risks posed by borrowers artificially shrinks the amount of available credit. ${ }^{164}$ Engel and McCoy more recently argue that securitization has eliminated such "credit rationing." 165 Rather, they assert, market segmentation permits lenders to exploit borrowers who lack accurate market information by charging them above-market rates. ${ }^{166}$ Such borrowers are typically those "disconnected from the credit market," many of whom "were historically excluded from the home-mortgage market because of credit rationing and discrimination."167

The secrecy of subprime mortgage rates at the retail level hinders efficiency in subprime mortgage markets. ${ }^{168}$ Both prime borrowers and subprime mortgage brokers are able to shop for capital using published rate tables. Subprime borrowers, in contrast, do not have access to such rate tables, which are not published by subprime originators. ${ }^{169}$ The prices offered subprime borrowers are effectively set by originators' chosen markup. ${ }^{170}$ Moreover, subprime mortgage rates are typically so complex

161. A subprime borrower is "overcharged" when her loan bears an interest rate and orgination fees that are incommensurate with the additional risk she poses as a borrower.

162. White, supra note 160 , at 504 .

163. Lax et al., supra note 110 , at 535 .

164. Joseph E. Stiglitz \& Andrew Weiss, Credit Rationing in Markets with Imperfect Information, 71 AM. ECON. REV. 393, 393 (1981). The credit rationing theory asserts that information asymmetries combine with adverse selection problems to cause lenders to artificially shrink the supply of available credit in order to identify good credit risks. The adverse-selection problem operates as follows: lenders want to lend to risk-averse borrowers because they are less likely to default, but risk-avcrse borrowers are more likely to be deterred by higher interest rates. Id. Risk-taking borrowers, in contrast, are more likely to default but less likely to be deterred by high interest rates. Id. According to Stiglitz and Weiss, because high rates will deter those borrowers to whom lenders wish to lend, lenders set artificially low loan prices. Id. at 394. At lower interest rates, demand exceeds supply and lenders have a pool of potential borrowers from which to choose, allowing them to screen and reject high-risk borrowers. Id.

165. Engel \& McCoy, supra note 123, at 1278-79.

166. Id. at 1280 .

167. Id. Such "disconnected" borrowers are analogous to the "antimarket" consumers identified by Troutt: immobile urban poor who seek "economic survival, rather than economic stability" in the ghetto. Troutt, supra note 55, at 428-30.

168. White, supra note 160 , at 509 . ("The rate tables used by wholesalc subprime lenders are available only to brokers and are sometimes regarded as trade secrets.").

169. Id.

170. Id. at 512 . 
that even with perfect price transparency comparison shopping would be difficult. ${ }^{171}$

The segmentation of the subprime market from its prime counterpart frustrates comparison shopping between the two. Empirical evidence of a price discontinuity between the prime and subprime interest rates suggests that such segmentation exists and that subprime loans are overpriced. ${ }^{172}$ In an efficient market, one would expect that "interest rates for a spectrum of consumers with the best- to the worst-quality credit would be continuous." 173 Instead, it is "an observable and enduring feature" of the mortgage market that the lowest subprime interest rate is generally two percentage points higher than the highest prime rate. ${ }^{174}$ This gap in pricing alone reveals that there is a lack of crossover from subprime to prime markets and that some borrowers at the top of the subprime risk pool have been overcharged. ${ }^{175}$ Segmentation of the prime from subprime markets limits the range of borrowers' perceived loan options, which facilitates exploitation. ${ }^{176}$

In the subprime market, risk may not be closely tied to price after all. Lenders lose money when a borrower defaults and either high foreclosure costs or insufficient revenues from foreclosure sale leave the lender with less than the full outstanding principal. But of all residential loan defaults, relatively few end in foreclosure, ${ }^{177}$ and though subprime foreclosure rates are higher than those in the prime market, losses to lenders are "typically less than $1 \%$ of the outstanding dollar balances annually." ${ }^{178}$ Lenders recover delinquency costs through late fees and other charges. ${ }^{179}$ Foreclosure is expensive, but subprime lenders account for this by limiting the loan-tovalue ratio to $65 \%$ to $75 \%$ (compared to a limit of $80 \%$ in the prime

171. Engel \& McCoy, supra note 123, at 1284 (comparing prime mortgage with "payment terms that are relatively easy to analyze" with predatory loans with terms "that require borrowers to make difficult probabilistic computations about the likelihood and magnitude of future market events").

172. Id. at 513 .

173. Id.

174. Id.

175. Engel \& McCoy, supra note 123, at 1280-81.

176. See, e.g., Honorable v. Easy Lifc Real Estate Sys., 100 F. Supp. 2d 885, 888 (2000) (noting defendants were able to charge "above-market prices [for rehabbed homes] by, in effect, taking the unsophisticated, first-time buyers ... out of the competitive market by ... controlling their access to potential properties, loans, down payments, attorneys and all other information") ). The Honorable court went on to quote Hanson and Kysar's argument "that 'market outcomes frequently will be heavily influenced, if not determined, by the ability of one actor to control the format of information, the presentation of choices, and, in general, the setting within which market transactions occur." Id. (quoting Jon G. Hanson \& Douglas Kysar, Taking Behavioralism Seriously: The Problem of Market Manipulation, 74 N.Y.U. L. REv. 630, 655 (1999)).

177. Elizabeth Renuart, Commentary, Toward One Competitive and Fair Mortgage Market: Suggested Reforms in A Tale of Three Markets Point in the Right Direction, 82 TEX. L. REv. 421, 427-28 (2003).

178. White, supra note 160 , at 507-08.

179. Renuart, supra note 177 , at 428 . 
market) with the differential between the home's market price and the value of the loan covering the costs associated with foreclosure. ${ }^{180}$

It may be argued that if borrowers truly overpaid for loans, other lenders would seize the opportunity to capture the market with lower rates. Moreover, the true magnitude of any mortgage risk is always subject to exogenous market forces. Definitive answers to the subprime pricing question require empirical analysis beyond the scope of this Comment. Here, it may be enough to note that mortgage markets have long been recognized as inefficient, and market segmentation, lack of price transparency, and information asymmetries now allow lenders to seek rents through pricing incommensurate with the risk they assume. When a borrower's willingness to pay, rather than the forces of an efficient market, dictatcs loan pricing, the stage is set for exploitation. Lenders need only identify borrowers willing to pay above-market rates. ${ }^{181}$ When willingness to pay correlates with residence in a formerly redlined area, targeting overpriced loans to such borrowers constitutes housing discrimination.

\section{Causes of the Geographic Concentration of Subprime Lending}

\section{Capital Flows: Gentrification and Unequal Access to "Good" Credit Opportunities}

In the $1990 \mathrm{~s}$, increased investment in real property laid the groundwork for the expansion of subprime lending. Political economists have linked booms in real property investment to periods in the business cycle when excesses of capital make profitable investment opportunities in the production sector hard to identify. ${ }^{182}$ During the stock market boom of the 1990s, significant amounts of capital were available to flow into realproperty-based investments. As securitization linked global capital and residential real estate, mortgage transactions became standardized and depersonalized. Housing value transitioned "from a dwelling use-value to a debt-encumbered portfolio asset." 183 This shift toward an increasingly investment-based function of mortgage lending caused money to flow into communities that, only decades earlier, had been explicitly redlined and then only reluctantly served by mainstream banks and mortgage insurers. ${ }^{184}$

180. Id.

181. Lenders' strategies for doing so are addressed infra in Part II.C.4.

182. Wyly et al., supra note 25 , at 629 ("[P]roperty booms are a leading indicator of recession and crisis, appearing as a 'kind of last-ditch hope for finding productive uses for rapidly overaccumulating capital."' (citing David Harvey, The Urbanization of Capital (1985)).

183. Id. at $631 \mathrm{n} .5$ ("There is considerable evidence, drawn from a variety of sources, of a structural expansion in residential mortgage lending over the past 15 or so years; indeed, some measures of growth suggest that we may be seeing a partial disengagement of residential capital flows from the traditional sources of mortgage demand.").

184. Id. at 663 (finding strong empirical support for the hypothesis that " $[t]$ he restructuring of financial serviccs that culminated in the late 1990 s created new linkages between the reinvested inner 
With houses defined as a "portfolio asset," dormant equity in so-called cash-poor, house-rich neighborhoods came to represent potentially lucrative profit streams. This effect was most pronounced in gentrifying areas where property values were rising dramatically. ${ }^{185}$

As capital flowed into gentrifying inner cities, simple geographic redlining became more difficult, and new forms of market segmentation became necessary for profit maximization. ${ }^{186}$ After modeling loan and lender data, scholars have concluded that "[i]nner city reinvestment creates landscapes where deep-pocket prime banks are pursuing wealthy (and predominantly white) gentrifiers alongside firms marketing to low-and moderate-income borrowers (mostly black)." 187 Unsurprisingly, the lowerincome segment of the market is dominated by subprime lenders. Thus, even as gentrification brought mainstream bank capital to formerly redlined neighborhoods, "good" credit opportunities were largely directed to wealthy white gentrifiers and denied to existing residents of lower-income and racial minority status. ${ }^{188}$ Although Wall Street capital has found its way to the inner city, when sought by longtime residents of such areas, it is often delivered through middlemen at a considerable markup.

\section{Creditworthiness: The Increasing Role of FICO Scores in Underwriting Subprime Loans}

The concentration of subprime lending is in part caused by increasing reliance on Fair, Isaacs and Company (FICO) credit scores to assess a borrower's creditworthiness. Credit scoring, which has been described as constituting a "sort of economic opportunity rating," 189 raises equality concerns because blacks are three times more likely than whites to have a high-risk credit score. ${ }^{190}$ In addition, a correlation exists between the prevalence of low credit scores and the pcrcentage of minorities in a given zip code. ${ }^{191}$ As discussed infra in Part II.C.4, lenders may use low credit scores as proxies for profitability, targeting high-cost loan products to neighborhoods where lower scores are concentrated.

\footnotetext{
city and national and international capital markets. Lenders restructured their operations and found new ways of reaching profit opportunities in parts of the city that were once seen as unacceptable risks.").

185. Id.

186. Id. at 632 .

187. Id. at 672

188. In fact, Wyly et al. found that "[a] black person requesting a loan in a core gentrified neighborhood is more than twice as likely to end up at a subprime lender than an otherwise similar black person elsewhere in the metropolitan area." Id.

189. IMMERGLUCK, supra note 10, at 265.

190. Fed. Trade Comm'n, Public Forum: The Consumer and Credit Scoring 122 (1999), available at http://www.ftc.gov/bcp/creditscoring/creditscorexscript.pdf [hereinafter FTC REPORT].

191. Robert B. Avery et al., Credit Scoring: Statistical Issues and Evidence from Credit-Bureau Files, 28 REAL Est. ECON. 523, 537 (2000).
} 
FICO scores, originally designed for use by credit card issuers, have played an increasingly large role in the underwriting of subprime loans. ${ }^{192}$ The scores are based on a model of the repayment behavior of a statistical set of borrowers with varying credit histories. ${ }^{193}$ FICO enjoys a virtual monopoly on the credit-scoring market and does not release the proprietary formula used to calculate scores. ${ }^{194}$

Some credit history features that may justify a loan denial, such as the existence of open consumer finance accounts or an insufficient credit history, work against borrowers from neighborhoods where traditional financing is unavailable. ${ }^{195}$ FICO scores appear to prefer track records of the right $k i n d$ of consumcr credit, disproportionately raising the scores of those who adhere to credit practices traditionally recognized as prudent ${ }^{196}$ and depressing the scores of those who have lived nontraditional economic lives. The fundamental problem is that the FICO formula cannot assess its indicia of creditworthiness in context. ${ }^{197}$ Subprime borrowers tend to "fall off the scale" of desirable credit scores. ${ }^{198}$ In apparent recognition of this bias against historically underserved borrowers, FICO developed a new credit scoring system for "non-traditional" borrowers with thin or no credit history. ${ }^{199}$ The mortgage industry seems to be more interested in that system than other credit providers. ${ }^{200}$

192. McCorkell, supra note 159 , at 210 .

193. STUART, supra note 58 , at 97.

194. FTC REPORT, supra note 190 , at 307.

195. In his defense of credit scoring, Peter McCorkell, vice president and general counsel of FICO, contends that "the[] data simply do not support the often-heard contention that giving negative weight to finance company usage necessarily disadvantages minority and low-income borrowers." McCorkell, supra note 159 , at 217.

196. FTC REPORT, supra note 190, at 30-32. For example, if a borrower's age, time at present address, time at current job, and homeownership status are all credit score factors, a borrower close to retirement who owns her own home and has held the same job for the bulk of her career is likely to receive high scores in each category. Her score will be boosted even if the predictive value of such redundant information is limited. FICO claims to accurately discount those factors that overlap in order to avoid artificially inflating scores. Id. Of course, without ability to peer into FICO's "black box," those on the outside will never know whether the company's procedures to mitigate redundancies are effective.

197. As Anthony Taibi notes, frequent changes of residence or employment lower the FICO score. Anthony D. Taibi, Banking, Finance, and Community Economic Empowerment: Structural Economic Theory, Procedural Civil Rights, and Substantive Racial Justice, 107 HARv. L. REv. 1463, 1469 (1994). Yet frequent changes of residence or employment may indicate that the borrower is committed to improving her family's quality of life and thus is actually a good credit risk. Moreover, the factors may penalize borrowers for circumstances beyond their control that do not affect an ability to repay. For instance, borrowers may have consumer finance accounts because they experienced discrimination by traditional credit providers. Finally, credit scores do not reflect participation in informal local economies that may amount to responsible economic behavior. Id.

198. WEICHER, supra note 147, at 36-37. Weieher's contention that FICO scores are thus not used in underwriting home loans appears to be outdated.

199. Brad Finkelstein, FICO Introduces 'Alternative' Credit Score, Nat'L MoRTGaGe News, Sept. 1, 2004, at 44.

200. Id. 
Furthermore, some subprime lenders may be preventing their primequalified customers from exiting the subprime market. Many subprime lenders have failed to report their borrowers' repayment habits to credit bureaus, making it more difficult for subprime borrowers to improve their credit scores and move into the prime market. ${ }^{201}$ Peter McCorkell, general counsel for FICO, speculates that the subprime lenders' underreporting may be an attempt to prevent their lower-risk subprime borrowers from being "picked off" by prime lenders. ${ }^{202}$

Finally, credit scoring exhibits the same self-reinforcing effects observed in the real estate appraisal context. When lack of credit history initially forces a borrower or consumer to accept higher fees or interest rates, the more expensive financing may affect the borrower's subsequent ability to pay, "justifying" a low credit score or further depressing it. Alternatively, Peter Swire posits that black borrowers expecting to face lending discrimination will rationally choose to under-invest in their own creditworthiness. ${ }^{203}$ Lenders respond by lowering the borrowers' credit ratings, beginning the cycle anew. ${ }^{204}$ In sum, lenders' increasing reliance on credit scores exacerbates the concentration of subprime lending in racial minority and low-income neighborhoods because FICO scores penalize the credit practices of historically underserved borrowers, and reflect inconsistent credit-reporting practices of subprime lenders.

\section{Separating Capital from the Site of the Deal: Depersonalization of the Lending Transaction}

Increased standardization of the lending process reinforces the geographic concentration of subprime lending by replacing personal borrowerlender relationships with risk-based pricing formulas that perpetuate historical discrimination. Structural changes in mortgage marketssecuritization, credit scoring, and automatic underwriting-have standardized lending procedures. However, increased use of automated underwriting and credit scoring may decrease borrowers' bargaining power regarding the specific terms of their home mortgages. ${ }^{205}$ Automation may have the most significant impact on those who have lived "non-traditional"

201. FTC REPORT, supra note 190, at 205.

202. Id. at 225 . The joint HUD-Treasury report agreed that subprime lenders may not be reporting some of their borrowers' good credit history information in order to "capture" those borrowers and prevent them from graduating to the prime loans to which their history of subprime payments might entitle them. HUD-TREASURY REPORT, supra note 14, at 6.

203. Peter P. Swire, Equality of Opportunity and Investment in Creditworthiness, 143 U. PA. L. REV. 1533, 1541 (1995).

204. Id. at 1535 . Swire bases his theory on a nationwide survey by the Federal Reserve that found that only $44 \%$ of black households maintain checking accounts as compared to nearly $80 \%$ of all other households. Id. at 1536 . Swire's theory appears to fit into patterns of self-reinforcing disinvestment that have been identified by several authors.

205. Id. 
economic lives. ${ }^{206}$ Also, "[s]ecuritization almost completely depersonalizes the lending process and deprives the borrower of the advantages of a personal relationship with her lender." ${ }^{207}$ Not only does this depersonalization reduce the chances of a loan being restructured to prevent default, but it focuses the loan originator's attention on achieving secondary market profits, rather than on finding a loan well-suited to a borrower's needs. ${ }^{208}$ Instead of serving borrowers, lenders must satisfy the "demands of distant investors and institutions" whose only interests are the profit stream represented by the securitized mortgage pool and the level of risk associated with it. ${ }^{209}$ This disjunction between the borrower and the ultimate beneficiary of the mortgage (the security holder) obscures what was once the hallmark of the industry: that both borrower and lender profited from the transaction.

As capital becomes separated from the site of the deal and "[p]ersonal and local relationships are exchanged for impersonal and distant monetary contacts, ${ }^{, 210}$ opportunities for bigoted loan officers to discriminate against prospective borrowers decrease. But automation paves the way for the exploitation paradigm of housing discrimination. ${ }^{211}$ Lending approval and pricing are now determined by complex equations of credit scores and collateral value. If these indices of risk - the real numbers in the lending equation-reflect historic inequities from now-illegal discrimination, using an algebraic formula to determine loan prices and terms will simply perpetuate the embedded inequities. When indicia of historic inequities are purposefully employed to target unsophisticated and underserved lenders for overpriced loans, such conduct should be considered actionable housing discrimination.

\section{Finding Profits: Intrafirm Segmentation and Targeted Loan Marketing}

Market segmentation, both between competing firms and within a single firm, allows lenders to maximize profits by aggressively marketing subprime loans to low-income and minority neighborhoods. The market for residential mortgage loans remains highly segmented. ${ }^{212}$ Interfirm market segmentation - the concentration of subprime lenders, finance companies, and pawn shops in low-income and minority neighborhoods and a corresponding concentration of elite federally-insured deposit banks in white

206. See supra note 195.

207. Eggert, supra note 116, at 565.

208. See supra Part II.A.2.

209. Robin Paul Malloy, Law and Market Economy: Reinterpreting the Values of LAW AND ECONOMICS 52 (2000).

210. Id. at 54.

211. Id. at 53 ("[C]oncerns for efficiency and profit maximization may actually increase the incidence of racial discrimination in the market for home mortgages.").

212. See, e.g., Engel \& McCoy, supra note 123, at 1270. 
neighborhoods-can trace its roots directly to the sordid history of bank redlining. ${ }^{213}$ However, as banks have been permitted to consolidate into large financial holding companies straddling both prime and subprime markets, they have developed a profit incentive to maintain their intrafirm market segmentation. ${ }^{214}$ Deregulation unleashed competitive forces that caused banks to fight for the most profitable borrowers, ${ }^{215}$ and the segmentation of retail lending markets increases profits by facilitating price discrimination within the customer base of a single firm. As one study notes, in gentrifying inner cities "[n]ew lines of stratified reinvestment are laid atop prior rounds of redlining, discrimination, and disinvestment. Institutional segmentation is replacing exclusion and credit rationing."216

Technology has facilitated concerted intrafirm market segmentation by enabling lenders to compile lists of customers with the geodemographic or credit history profiles they deem most profitable. ${ }^{217}$ Subprime loans are aggressively marketed to these populations, ${ }^{218}$ which tend to have lower levels of education and reside in "underserved" neighborhoods. ${ }^{219}$

Sophisticated consumer-profiling technologies have an especially pronounced impact on the distribution of subprime loans because most subprime loans are sold to, not sought $b y$, borrowers. ${ }^{220}$ By exploiting

213. See supra Part I.A.

214. Intrafirm segmentation is the division of the retail lending market into segments served by distinct affiliates or subsidiaries of the same parent financial institution. Intrafirm market segmentation is well-documented. See, e.g., Cal. Reinv. Comm., Stolen Wealth: Inequities in California's SubPrime Mortgage Market 46, 48 (2001) (finding that in Los Angeles, CitiGroup's subprime affiliate, CitiFinancial, was nearly four times as likely to loan to a lower-income borrower than its prime lending branch, Citibank; in Oakland, subprime lender CitiFinancial was nearly three times as likely to lend to black borrowers as it was to lend to whites).

215. See Timothy C. Lambert, Note, Fair Marketing: Challenging Pre-Application Lending Practices, 87 GEo. L.J. 2181, 2185 (1999) ("In this context, 'risk' is no longer defined in terms of default, but as the failure to be significantly profitable."). Lambert asserts a novel and compelling argument that fair lending laws should reach the pre-application practices of banks who fail to market to potential minority borrowers, thus systematically denying them access to credit. $I d$. A related arguinent may be built from Lambert's analysis: that lenders do market to minority communities, but that they offer credit on inferior terms, thus discriminating not in access to credit but in the terms and conditions on which it is offered.

216. Wyly et. al., supra note 25 , at 677

217. Lambert, supra note 215 , at 2185 ; Wyly et. al., supra note 25 , at 635 (noting that "automation in credit scoring and underwriting had the effect of reducing processing costs, offering new ways for lenders to find profitable borrowers in the inner cities").

218. See, e.g., Hargraves v. Capital City Mortgage Corp., 140 F. Supp. 2d 7, 21 (D.D.C. 2000) (noting that lender defendant made a "disproportionately large number of loans in neighborhoods that are over 90 percent black"); Brief for the United States, supra note 4, at 2 ("Since its inception in 1979, [defendants] have intentionally directed their marketing and loan solicitation efforts almost exclusively toward borrowers and properties in African American neighborhoods.").

219. HUD-TREASURY REPORT, supra note 14, at 37; Wyly et al., supra note 25 , at 672 . Lower credit scores also correlate with lower education levels and location im underserved neighborhoods, suggesting that low credit scores are proxies for profitability and an easy way to market high-priced loan products. See supra Part Il.C.2; Avery et al., supra note 191, at 537.

220. BRADFORD, supra note 16 , at 77 . 
disparities in borrowers' education, sophistication, financial desperation, or fear of discrimination at elite banking institutions, ${ }^{221}$ lenders can locate and target borrowers who are willing to pay more for loans. ${ }^{222}$ Subdividing the market and targeting potential customers by age, sex, income, education, occupation, ethnic origin, social class, and geography allows lenders to focus on proxies for profitability, directing more expensive loan products to those borrowers they believe will pay more. ${ }^{223}$

Moreover, if a subprime borrower qualifies for a prime loan, a subprimelender has no incentive to offer this borrower the prime rates that are available elsewhere in the lender's firm. Mortgage brokers lending a bank's money at a markup do not want to lose their customers and commissions to the bank's prime-market branches. ${ }^{224}$ The aggregation of profits at the parent company level belies the firm's profit motives for maintaining the segmentation of its own retail lending business.

Prime-market banks may also have public image reasons for keeping their subprime affiliates distinct, further contributing to the segmentation of the lending market. ${ }^{225}$ Such motivations are demonstrated by a district court's recent refusal to dismiss a fair lending case against subprime lender Equicredit or its parent, Bank of America. ${ }^{226}$ In Johnson v. Equicredit Corporation of America, the plaintiff alleged that in the Chicago area, Equicredit made its subprime loans almost exclusively in minority areas, while its parent, Bank of America, made prime loans to similarly situated whites in predominantly white areas. ${ }^{227}$ The Johnson plaintiffs did not argue that Bank of America should be held liable for the alleged discrimination of its subsidiary Equicredit. Rather, they claimed that Bank of America itself had violated the FHA, the Equal Credit Opportunity Act (ECOA), ${ }^{228}$ and 42 U.S.C. $\S 198$ I by providing "different types of loans

221. See Immergluck, supra note 10, at 124; Engel \& McCoy, supra note 123, at 1280; Swire, supra note 203, at 1541 .

222. Engel \& McCoy, supra note 123 , at $1280-81$. To exploit information asymmetries, lenders must "identify people who are disconnected from the credit economy and therefore unlikely or unable to engage in comparison shopping." Id. at 1281. Engel and McCoy assert that lower-income persons of color are most likely to meet these criteria and that such potential borrowers may be easily identified by use of HMDA or census data. Id.

223. Lambert, supra note 215 , at 2190-91.

224. As the general counsel for FICO recognizes, "Economically-disadvantaged neighborhoods are less likely to attract multiple mainstream lenders, so residents of those neighborhoods may have a hard time finding low-cost lenders even when they, individually, would qualify for prime rates." McCorkell, supra note 159, at 214.

225. Engel \& McCoy, supra note 123 , at 1289-90.

226. Johnson v. Equicredit Corp. of Am., No. 01 C 5197, 2002 WL 448991 (N.D. Ill. Mar. 22, 2002).

227. Id. at *1.

228. Pub. L. No. 90-321, 88 Stat. 1521 (1974) (codified as amended at 15 U.S.C. $§ 1691$ (2000)). 
depending on the racial demographics of the area in which the borrower resides." 229

The court's acceptance of the plaintiffs' proffered comparisonEquicredit's subprime borrowers with Bank of America's prime borrowers-is significant. Often, the failure to identify appropriate, "similarly situated" parties of another race for comparison is a crucial obstacle to establishing discrimination under a disparate treatment theory. ${ }^{230}$

Intrafirm segmentation of credit markets may be a new manifestation of the older, simpler geographic redlining. Just as redlining can be explained as a method of profit-maximizing by facilitating price discrimination, ${ }^{231}$ targeting market segments that display indices of profitability that correlate with protected categories of race, sex, or national origin can also allow for above-market pricing. Such exploitation of historical discrimination should be actionable under the FHA.

\section{III}

\section{Toward a New Fair Housing Doctrine}

When caveat emptor - the law's refusal to protect consumers from the consequences of their own economic decisions-conflicts with the FHA's purpose to ensure the fair provision of housing and eradicate the vestiges of state-sponsored segregation, the FHA's purpose should prevail. Courts, including the U.S. Supreme Court, have taken the "revolutionary" position that civil rights laws may sometimes trump the longstanding notion that the fairness of a freely bargained-for exchange is beyond the law's purview. ${ }^{232}$ When borrowers' loan options are limited due to historical discrimination in credit scoring, home appraisal, and redlining, purposeful exploitation of these conditions should be, in itself, actionable discrimination. Given the changing face of mortgage markets-new dynamics, incentives, and agents-and more complete understandings of how prime and subprime

\footnotetext{
229. Johnson, 2002 WL 448991 , at *5.

230. See infra notes $235-246$ and accompanying text

231. See supra notes $46-50$ and accompanying text.

232. See Contract Buyers League v. F \& F Inv., 300 F. Supp. 210 (N.D. II. 1969) (summarizing the Supreme Court's reasoning in Jones v. Alfred H. Mayer Co., 392 U.S. 409 (1968), that Section 1982 could require the recision or reformation of any transaction in which it is alleged that one was charged more than another on account of one's race). The Contract Buyers League court continued:

[W] hat ... defendants call "revolutionary" ... is simply a denial of their assumption that there is a necessary sanctity in the status quo. Defendants present the discredited claim that it is necessarily a right for a businessman to secure profit wherever profit is available, arguing specifically with respcct to this case that they did not create the system of de facto segregation which was the condition for the alleged discriminatory profit. But the law in the United States has grown to define certain economic bounds and ethical limits of business enterprise.... [I]t is now understood that... there cannot in this country be markets or profits based on the color of a man's skin.
} 
loans are priced, marketed, and approved, courts should be open to new arguments that fit within the broad remedial purpose of Title VIII.

\section{A. Origin and Failings of Title VIII Doctrine}

Much of the case law interpreting Title VIII originates from Title VII employment discrimination doctrine. ${ }^{233}$ Although some employment discrimination doctrine is applicable by analogy to the housing discrimination context, the importation of Title VII doctrine into Title VIII jurisprudence has been at times irregular and ill fitting. Circuit courts have split in determining the manner in which Title VII's discrimination analysis and burden-shifting regimes should apply in the fair housing context. ${ }^{234}$ If the employment discrimination doctrine applies only imperfectly in fair housing cases alleging binary discrimination (the denial of a housing opportunity to a member of a protected class in favor of a white applicant), the doctrine even less effectively addresses the exploitation model of housing discrimination represented by racially concentrated subprime lending.

\section{Disparate Treatment and the "Comparison Approach" to Housing Discrimination}

Perhaps the most ill-fitting doctrine imported from employment discrimination law into FHA cases alleging residential loan discrimination ${ }^{235}$ is the disparate treatment test, first enunciated by the U.S. Supreme Court in McDonnell Douglas Corporation v. Green. ${ }^{236}$ Under a disparate treatment test, or "comparison approach," 237 to discrimination, a member of a protected class may establish a prima facie case of discrimination by showing that she was qualified for a job (or home loan) and a person not belonging to that protected class was given the job (or home loan) instead. ${ }^{238}$ Once

233. See, e.g., Huntington Branch, NAACP v. Town of Huntington, 844 F.2d 926, 934 (2d Cir. 1988) ("[W]e have pointedly accepted the relevance of Title VII cases to Title VIII cases.").

234. See infra Part III.A.2.

235. Such cases can allege violations of the FHA sections addressed supra in Part 1.C.1. Section 3604(a) is implicated when a plaintiff alleges that through systemic discrimination a lender has effectively made housing unavailahle to the plaintiff or other members of her protected class. Section 3604(b) applies when the terms and conditions of a home purchase loan are alleged to be discriminatory. Section 3605 operates when the terms or conditions of a home purchase, home improvement, or home equity loan are allegedly discriminatory.

236. 411 U.S. 792 (1973).

237. Because the disparate treatment test necessitates the comparison of similarly situated parties, I refer to it as the "eomparison approach."

238. Id. at 802. The Court in McDonnell Douglas set out a four-part standard for establishing a prima facie case of illegal employment discrimination. That standard requires that the plaintiff establish:

(i) that [an individual] belongs to a racial minority; (ii) that he applied and was qualified for a job for which the employer was seeking applicants; (iii) that, despite his qualifications, he was rejected; and (iv) that, after his rejection, the position remained open and the employer continued to seek applicants from persons of complainant's qualifications. 
a prima facie case is established, the burden shifts to the defendant to proffer a nondiscriminatory reason for choosing the successful applicant over the protected-class-member applicant. ${ }^{239}$

A plaintiff can establish discriminatory intent by showing that the defendant treated similarly situated parties differently because of their race. ${ }^{240}$ Discrimination need not be the defendant's goal, ${ }^{241}$ but the mental element of "treating a person differently because of the person's race" is required. ${ }^{242}$ In practice, proving discriminatory intent requires comparing parties that are identical in every respect except race, and isolating racial discrimination as the only possible explanation for why they were treated differently. Thus, the existence of similarly situated individuals of different races is a prerequisite for McDonnell Douglas burden shifting.

As noted in Latimore, comparison of similarly situated individuals seems inappropriate in analyzing typical credit discrimination allegations; simply put, "Latimore was not competing with a white person for a \$5I,000 loan." ${ }^{243}$ At the individual level, loans, unlike homes or jobs, are not given to one party to the exclusion of another. ${ }^{244}$ The court conceded that Latimore might establish a prima facie case of discrimination under a "kind of McDonnell Douglas knock off" approach by showing that an "equally creditworthy" white loan applicant with comparably valued collateral received a loan from Citibank at about the same time that Latimore was denied. ${ }^{245}$

In reality, it is difficult to establish that similarly situated white and non-white loan applicants experienced different outcomes on account of their race, because they are often different in many other respects. Latimore thus illustrates the limitations of disparate treatment theory in redressing the type of discrimination implicit in Latimore's claim; namely, that because of her race and her neighborhood's racial makeup, she was forced into the subprime market even though she qualified for the prime

Id. Upon establishing these four elements, the burden shifts to the employer to articulate a "legitimate, nondiscriminatory reason" for the applicant's rejection. Id.

239. Id.

240. Vill. of Bellwood v. Dwivedi, 895 F.2d 1521, 1530 (7th Cir. 1990) ("The judge can elide the question of intent, however, by simply instructing the jury that the unlawful conduct is treating a person differently because of the person's race, as distinct from treating a person differently because of other, noninvidious characteristics which may be correlated with race.").

241. Id. at 1531 ("Discrimination may be instrumental to a goal not itself discriminatory, just as murder may be instrumental to a goal not itself murderous (such as money).").

242. Id. at 1530 .

243. Latimore v. Citibank Fed. Sav. Bank, 151 F.3d 712, 714 (7th Cir. 1998). Courts have held elsewhere that the McDonnell Douglas burden-shifting regime may apply to Title V1lI claims. See Vill. of Bellwood, 895 F.2d at 1531.

244. Latimore, 151 F.3d at 714 ("[I]t is the competitive situation-the black facing off as it were against the white-that creates the (minimal) suspicion [of racial discrimination], and there is no comparable competitive situation in the usual allegation of credit discrimination.").

245. Id. at 715 . 
market. The litany of cases in which individual plaintiffs alleging credit discrimination have failed is a testament to this difficulty. ${ }^{246}$

On the other hand, some courts have correctly rejected the comparison approach when its analytic framework would be unfair to plaintiffs. ${ }^{247}$ In Clark v. Universal Builders, Inc. (Clark I), the plaintiffs alleged discrimination in violation of 42 U.S.C. $\S 1982$ due to the "onerous terms" of home sales in black neighborhoods. ${ }^{248}$ There, the appellate court found error in the district court's use of the "traditional" comparison approach and its assertion that "absent evidence of defendants' sales of the same or similar housing to whites on more favorable terms ... plaintiffs failed to make out a case of liability."249 The appellate court in Clark I sharply rejected the defendants' argument that they would have sold the same property on the same terms to whites. ${ }^{250}$ The court concluded that '[t]o accept defendants' contention would be tantamount to perpetuating a subterfuge behind which every slumlord and exploiter of those banished to the ghetto could hide."251 Given the FHA's broad purpose to end racial segregation, the Clark I court correctly rejected the comparison approach by finding it inapposite to the allegations of discrimination at issue.

\section{The FHA's Discriminatory Effects Standard}

When plaintiffs cannot prove the discriminatory intent necessary for a disparate treatment claim, under the FHA they may instead prove disparate impact. Proof of discriminatory intent is not required to establish liability under a disparate impact theory. ${ }^{252}$ Indeed, Title VIII's broad purpose to

246. See, e.g., Sallion v. Suntrust Bank, 87 F. Supp. 2d 1323 (N.D. Ga. 2000) (finding that plaintiff loan applicant's ECOA claim failed under the McDonnell Douglas framework for inability to establish that he was qualified for the loan in question); Cooley v. Sterling Bank, 280 F. Supp. 2d 1331 (M.D. Ala. 2003) (rejecting credit applicant's FHA, ECOA, and 42 U.S.C. $\S 1981$ claims under the McDonnell Douglas framework for failure to show plaintiff was similarly situated to successful nonminority applicants); Rowe v. Union Planters Bank, 289 F.3d 533 (8th Cir. 2002) (finding that loan applicant's FHA and ECOA claims failed under disparate treatment test for inability to produce evidence that applicant was qualified for loan).

247. See, e.g., Clark v. Universal Builders, Inc., 501 F.2d 324, 331 (7th Cir.), cert. denied, 419 U.S. 1070 (1974) (Clark l) ("lt is no answer that defendants would have exploited whites as well as blacks.").

248. Id. at 327 .

249. Id. at 328 .

250. Id. at 331 .

251. Id. at 331 .

252. See, e.g., United States v. Yonkers Bd. of Educ., 837 F.2d 1181, 1217 (2d Cir. 1987); Simms v. First Gibraltar Bank, 83 F.3d 1546, 1555 (5th Cir. 1996); see also John C. Dubin, From Junkyards to Gentrification: Explicating a Right to Protective Zoning in Low-Income Communities of Color, 77 MinN. L. REv. 739, 784-85 (1993) (“[T] here is no circuit conflict on this point, with courts in virtually every circuit having approved some version of a discriminatory effects standard under the Fair Housing Act."). 
remedy de facto segregation mandates such treatment. ${ }^{253}$ In permitting a plaintiff to establish housing discrimination without proving intent to discriminate, courts have recognized both the potential dangers of purportedly neutral practices that produce disparate outcomes ${ }^{254}$ and the practical difficulties of proving discriminatory intent. ${ }^{255}$ One appeals court recognized the necessity of an "effects only" standard because of defendants' ability to obscure their true discriminatory motives. ${ }^{256}$ Significantly, that court found that the district court erred in failing to consider the "historic context" of the challenged practice in its analysis of the practice's discriminatory effects. ${ }^{257}$

Although circuit courts differ on the precise contours of the discriminatory effects standard for establishing a prima facie case under the FHA ${ }^{258}$ it is generally accepted that a plaintiff bears the initial burden of showing that the challenged practice produces racially disparate outcomes. Once a plaintiff makes a prima facie case, a defendant may proffer legitimate, nondiscriminatory reasons for the disparate results. A plaintiff need not prove that the defendant's justifications wcre pretextual under the disparate impact approach. Rather, a court must consider (1) whether the defendant's nondiscriminatory reasons are bona fide and legitimate, and (2) whether any less discriminatory alternative can serve those ends. ${ }^{259}$ In effect, a court must balance the benefits of any less discriminatory alternatives with the burden imposed on a defendant implementing such alternative measures.

253. Huntington Branch, NAACP v. Town of Huntington, 844 F.2d 926, 934 (2d Cir. 1988) ("The Act's stated purpose to end discrimination requires a discriminatory effect standard; an intent requirement would strip the statute of all inpact on de facto segregation.").

254. Hobson v. Hansen, 269 F. Supp. 401,497 (D.D.C. 1967) ("Whatever the law was once, ... we now firmly recognize that the arbitrary quality of thoughtlessness can be as disastrous and unfair to private rights and the public interest as the perversity of a willful scheme.").

255. United States v. City of Black Jack, 508 F.2d 1179, 1185 (8th Cir. 1974) (noting that "clever men may easily conceal their motivations").

256. Id. (noting that "[e]ffect, and not motivation, is the touchstone" of Title Vlll liability).

257. Id. at 1186 .

258. See Kristopher E. Ahrend, Effect, or No Effect: A Comparison of Prima Facie Standards Applied in "Disparate Impact" Cases Brought Under the Fair Housing Act (Title V1II), 2 RACE \& EThNic ANC. L.J. 64 (1996). The Second Circuit considered the alternative approaches and ultimately settled on a formulation of the disparate impact approach derived directly from the Supreme Court's interpretation of Titlc VI1 in Griggs v Duke Power Co., 401 U.S. 424 (1971): statistical evidence of disparate impact is sufficient to establish a prima facie case. Huntington Branch, 844 F.2d at 926. The Eighth Circuit held that a plaintiff need prove only that a defendant's practice "actually or predictably results in racial discrimination." City of Black Jack, 508 F.2d at 1184-85. The Seventh Circuit has set forth a "four-factor" inquiry to guide a court's analysis. Metro. Hous. Dev. Corp. v. Vill. of Arlington Heights, 558 F.2d 1283, 1290 (7th Cir. 1977).

259. See Huntington Branch, 844 F.2d at 939; see also Resident Advisory Bd. v. Rizzo, 564 F.2d 126 (3d Cir. 1977). To justify a practice that may be objectively neutral but discriminatory in outcome, defendant must show (1) that the practice served a legitimate, bona fide, business interest, and (2) no alternative course of action could have been taken that would have enabled their interest to be served with less disparate impact on black applicants. See id. at 149. 
In Village of Bellwood v. Dwivedi, the Seventh Circuit held that disparate impact theory is unavailable when the allegations at issue do not justify its application. ${ }^{260}$ Similar to the Latimore court's holding that disparate treatment analysis is inapplicable to discrimination resulting from the consistent application of facially neutral policies, ${ }^{261}$ the Village of Bellwood court declined to apply disparate impact analysis to allegations against real estate agents for illegal racial steering. ${ }^{262}$ To allow disparate impact analysis, the court reasoned, would unfairly hold the agents liable for following their customers' preferences, which produced a disparate result in the aggregate. ${ }^{263}$ The court's refusal to apply disparate impact analysis, however, must be confined to cases in which discriminatory intent necessarily accompanies the discriminatory conduct alleged. Racial steering-directing customers to neighborhoods because of their race-of necessity entails an intent to treat individuals differently on account of their race. ${ }^{264}$

As this Part has illustrated, courts in housing discrimination cases exercise substantial discretion in adopting the analytical framework best suited to the facts they are called upon to consider. The withholding of the disparate treatment approach in Latimore ${ }^{265}$ and the disparate impact approach in Village of Bellwood ${ }^{266}$ are prime examples of this discretion. As will be discussed in the next Part, the flexibility of fair housing doctrine supports the creation of new analytical frameworks that can adequately assess the discrimination constituted by concentrated subprime lending.

\section{B. The Need for a New Theory of Housing Discrimination}

Private plaintiff suits are the FHA's primary enforcement mechanism. ${ }^{267}$ Under the FHA, a fact-finder uses judicially created, pragmatic

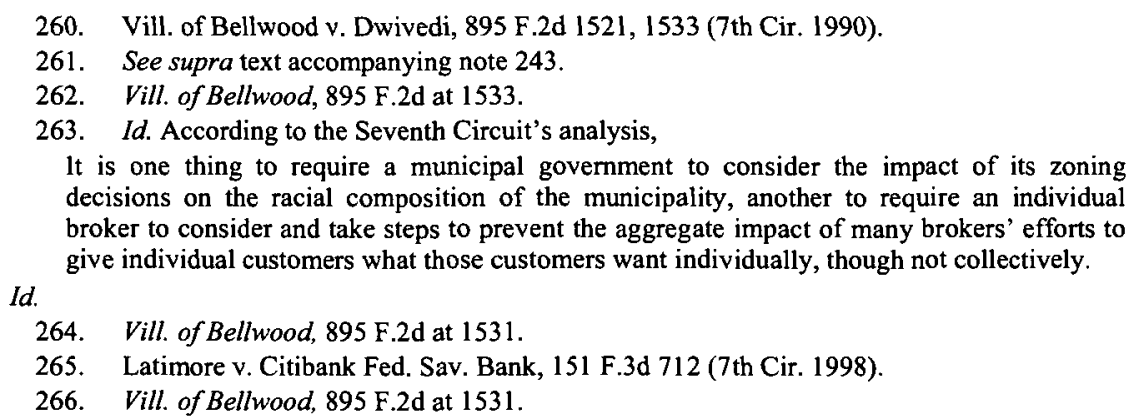

264. Vill. of Bellwood, 895 F.2d at 1531.

265. Latimore v. Citibank Fed. Sav. Bank, 151 F.3d 712 (7th Cir. 1998).

266. Vill. of Bellwood, 895 F.2d at 1531 .

267. See Trafficante v. Metro. Life lns. Co., 409 U.S. 205, 211 (1972) ("[T]he main generating force must be private suits in which, the Solicitor General says, the complainants act not only on their own behalf but also as private attorneys general in vindicating a policy that Congress considered to be of the highest priority" (internal quotations omitted).). The Act's reliance on private suits for enforcement has been called its "fundamental weakness." MASSEY \& DENTON, supra note 28, at 198. A victim of alleged housing discrimination may also file a complaint with HUD which will investigate the claim and attempt to resolve it without resort to litigation. Frank Lopez, Note, Using the Fair Housing Act to Combat Predatory Lending, 6 Geo, J. on PoverTy L. \& PoL'y 73, 93 (1999). Attorneys general 
devices to determine whether illegal discrimination has occurred. Showings of discriminatory effects and disparate treatment are merely evidence of a violation, ${ }^{268}$ and this evidence must be considered in the larger context of the challenged conduct. ${ }^{269}$ As new forms of discrimination evolve, so should the doctrinal frameworks under which they are assessed.

Given new understandings of the subprime mortgage market, racially concentrated subprime lending in formerly redlimed areas should be treated as violating several of the FHA's provisions. These violations include: (1) denying "financial assistance" (in the form of home mortgage loans with an interest rate fairly tied to borrower's level of credit risk) in violation of Section 805 ; (2) making housing unavailable in violation of Section 804(a) by systematically diminishing home equity in communities of color with loans made without regard for borrowers' ability to repay them ; and (3) discriminating in the "terms and conditions" of housing sales in violation of Section 804(b) by aggressively marketing home loans according to proxies for unsophistication that also correlate with historic discrimination.

Given the FHA's broad purpose and precedent supporting its expansive interpretation to remedy segregation's effects, novel arguments supported by strong empirical data regarding market conditions are important tools in combating the harmful effects of racially concentrated subprime lending.

\section{A Better Approach: The Exploitation Theory}

Some courts, cognizant of the unique nature of housing markets, have scrutinized the context in which allegedly discriminatory residential loans were made and, in so doing, breathed new life into the "exploitation theory" of discrimination, first propounded in Clark $1 .{ }^{270}$ Called "novel, innovative and serious" by one court, ${ }^{271}$ the theory represents a significant step toward a fair housing doctrine equipped to address the discrimination constituted by concentrated subprime lending. Fundamentally, the exploitation theory holds that a lender nay be liable for housing discrimination if (1) a segregated housing market exists and (2) the lender unreasonably exploits such market conditions. ${ }^{272}$

\footnotetext{
may bring Title VIII cases based on a "pattern or practice" of housing discrimination or an "issue of general public importance." 42 U.S.C. \$ 3614(a) (1988).

268. Vill. Of Bellwood, 895 F.2d at 1534.

269. United States v. City of Black Jack, 508 F.2d 1179, 1 I86 (8th Cir. 1974).

270. Clark I, 501 F.2d 324, 324 (7th Cir.), cert. denied, 419 U.S. I070 (1974).

271. Honorable v. Easy Life Rcal Estate Sys., 100 F. Supp. 2d 885, 888 (N.D. Ill. 2000).

272. Id. at 887 .
} 


\section{a. The Exploitation Theory is Born: Clark I}

In Clark $I$, the plaintiffs alleged that the defendants exploited a dual, segregated housing market by selling them homes in black areas at prices far exceeding those paid by white buyers for comparable homes in neighboring areas. ${ }^{273}$ The plaintiffs stated a claim under 42 U.S.C. $\S 1982$ by alleging: "(I) as a result of racial residential segregation dual housing markets exist and (2) defendant sellers took advantage of this situation by demanding prices and terms unreasonably in excess of prices and terms available to white citizens for comparable housing. ${ }^{9274}$ The court rejccted the defendants' argument that they offered the plaintiffs the same loan terms that they would have offered whites, because such an argument "ignores current realities of racial psychology and economic practicalities."275 Thus, the Clark I court rejected the formalistic boxes of disparate treatment doctrine when "current realities" (the continuing impact of historical discrimination, for example) made analysis under such a framework inappropriate. ${ }^{276}$ In allowing the claim to proceed absent any comparison to the defendants' treatment of similarly situated whites, ${ }^{277}$ the court established a new theory of discrimination that allowed plaintiffs to challenge conduct allegedly violating the FHA's purpose, namely, "prolong[ing] and perpetuat[ing] a system of racial residential segregation." 278

After examining the market conditions for housing available to blacks, the court rejected the defendants' argument that their conduct was "solely a matter of economics and not of discrimination."279 The court drew a picture of the black housing market as a failed market in which the supply and demand for housing in black areas was "affected by a contrived market condition which is grounded in and fed upon by racial discrimination." 280 Precisely because the defendants exploited market conditions to extract excessive prices from black buyers, the court ruled that the defendants' actions were "[not] triggered...by an economic phenomenon but by a pattern of discrimination that has no place in our society. ${ }^{281}$

As illustrated by Clark I, the exploitation theory uses the socioeconomic conditions of segregation as the predicate for a court's inquiry into the reasonableness of a defendant's conduct. If a segregated housing

\footnotetext{
273. Clark I, 501 F.2d at 327.

274. Id. at 334 .

275. Id. at $330-31$.

276. Id.

277. Id. at 331 ("It is no answer that defendants would have exploited whites as well as blacks."). The court compared the actual prices defendants charged blacks with the market prices of comparable housing available to whites.

278. Id.

279. Id.

280. Id.

281. Id. at 332 .
} 
market exists, and if a defendant unreasonably takes advantage of this condition, then a plaintiff may state a claim of discrimination. ${ }^{282}$

Under the exploitation theory, liability often turns on the economic reasonableness of a defendant's conduct, rather than whether he treated like people differently on account of race. ${ }^{283}$ The Clark $I$ court noted that differing prices offered to blacks and whites "due to a myriad of permissible factors can be expected and are acceptable,"284 but the court emphasized that civil rights statutes would be enforced against those who "exploit a discriminatory situation under the guise of artificial differences. ${ }^{285}$ Applying the court's reasoning to the context of residential mortgage lending, the exploitation theory protects a lender's legitimate consideration of a borrower's financial profile. However, the theory prohibits the exploitative use of "artificial differences" created by socioeconomic forces beyond any single defendant's control. Such "artificial differences" might include the exploitative market segmentation within a single firm, where the price of loans reasonably available to a borrower is dictated by geography rather than that borrower's risk profile.

\section{b. Development of the Exploitation Theory}

The exploitation theory ultimately proved unsuccessful for the Clark plaintiffs when, ten years after Clark $I$, the Seventh Circuit failed to find clear error in the trial court's ruling for the defendants on the merits. ${ }^{286}$ The Clark II court held that although the plaintiffs "succeeded in painting a deplorable picture of the discrimination reflected in Chicago housing patterns during the period in question," such evidence was insufficient to establish liability without showing that "market conditions could have presented the defendants with the opportunity to exploit the market by charging plaintiffs unreasonably high prices.".287

In Harris v. Wisser ${ }^{288}$ a district court applied the Clark I exploitation theory in the context of a home sale to black purchasers at a price well above fair market value. The Harris plaintiffs alleged that a seller of real property had rejected their initial offer and conspired with a third party, the defendant, to sell the property to them for a substantial profit. ${ }^{289}$ The plaintiffs alleged that the defendant perpetrated the scheme against them because of their race. ${ }^{290}$ Stating that " $[t]$ here is no reason to believe the court

282. See id. at 330 ("[S]ection 1982 is violated if the facts demonstrate that defendants exploited a situation created by socioeconomic forces tainted by racial discrimination.").

283. Id. at 333 ("[T]he benchmark for guiding a seller's conduct . . . is reasonableness.").

284. Id.

285. Id.

286. Clark v. Universal Builders, lnc., (Clark II) 706 F.2d 204, 211 (7th Cir. 1983)

287. Id.

288. 514 F. Supp. 1153 (E.D. Wis. 1981).

289. Id. at 1154 .

290. Id. 
of appeals intended Clark [ $I]$ to be narrowly confined to its particular facts," the Harris court held that the plaintiffs stated a claim under 42 U.S.C. $\S 1982 .{ }^{291}$ The court held that the plaintiffs' failure to explain why they agreed to purchase the property at the inflated price did not bar their claim. ${ }^{292}$ The court's reasoning contradicted a fundamental premise of economics, namely that a consumer's willingness to pay a given price indicates that the amount is fair. Rather than be bound by economic theory, the Harris court held that the above-market price constituted a civil rights violation and was the result of exploitation of an "impermissible consideration of race."'293

In Clark II, the exploitation theory fell short without evidence that defendants had sufficient market power either to charge higher prices or to offer inferior terms as compared to those offered by their competitors in the area. However, to succeed under the exploitation theory, plaintiffs need only present "an economically credible explanation of how an exploiter can stay in business charging above-market prices. ${ }^{" 294}$ Given the information asymmetries that characterize subprime lending markets, such "economically credible explanations" need not amount to market power in the strict economic sense. ${ }^{295}$ Rather, the exploitation theory permits plaintiffs to introduce evidence of the context in which the alleged discrimination occurred. Relevant contextual factors may include a lender's purposeful targeting of particular demographic groups or willful circumspection of borrowers' perceptions of their own options-and the conditions of the subprime lending market more generally. Thus, the exploitation theory is an important step toward a fair housing doctrine that properly understands both the historic and ongoing inequity inherent in racially concentrated subprime lending.

\section{c. Recent Application of the Exploitation Theory}

In Honorable v. Easy Life Real Estate System, the district court's reliance on economic theories of market failure was explicit. The plaintiffs challenged the defendant's sale of rehabilitated homes in a predominantly black area of Chicago, claiming that the sellers took advantage of the buyers' lack of sophistication in a racially discriminatory way. ${ }^{296}$ Relying on the exploitation theory, the court held that the plaintiffs stated a claim under the FHA. The first element of the exploitation theory, the existence of

\footnotetext{
291. Id. at 1156 .

292. Id.

293. Id

294. Honorable v. Easy Life Real Estate Sys., 100 F. Supp. 2d 885, 887 (N.D. Ill. 2000)

295. Id. ("Market power based in market share is just one way to show the mechanism by which the exploitation occurs. A plaintiff may show others.").

296. Id. at 886 .
} 
dual housing markets, was not in dispute 297 because the defendants argued only that they lacked the requisite market power to exploit a dual housing market. ${ }^{298}$ In response, the plaintiffs contended that the defendants "were able to exploit African-Americans by carving out a noncompetitive enclave in the market." 299 According to the plaintiffs, the defendants achieved the functional equivalent of market power over the "unsophisticated, first-time minority buyers who had the misfortune to fall into their clutches" 300 by controlling the forms of information and range of choices that the plaintiffs were offered. ${ }^{301}$

The defendants argued that because rational consumers will always seek out the lowest price available, the plaintiffs could not truly have been confined to the defendant's loans. ${ }^{302}$ The court, however, noted that the defendant's economic argument was only as strong as the assumptions upon which it was based, namely, that a consumer's ability to obtain the lowest available price is contingent on the availability of market information. ${ }^{303}$ The court concluded that the conditions of the relevant housing market did not support the assumption that first-time minority homebuyers will necessarily seek and obtain the lowest price available. ${ }^{304}$ Moreover, the court noted that consumer behavior in housing markets does not match perfect consumer rationality "because of the special characteristics of the product and the complexity of the transaction." 305

Although the plaintiffs in Honorable survived summary judgment, the court still required them to show that "racial discrimination was involved" 306 in the exploitation. One interpretation of this statement would

\section{Id. at 887 .}

298. Id.

299. Id. at 888 .

300. Id. The court specifically disavowed "class snobbery or patemalism" because the plaintiffs themselves argued they lacked "the information, confidence, and experience to be 'normal' consumers." Id. The judge did no inore than "take [them] at their word." Id.

301. Id. The court noted that the plaintiffs' argument follows the behavioral analysis discussed by Jon D. Hanson \& Douglas A. Kysar in Taking Behavioralism Seriously: The Problem of Market Manipulation, 74 N.Y.U. L. REv. 630, 635 (1999).

302. Honorable, $100 \mathrm{~F}$. Supp. $2 \mathrm{~d}$ at 889.

303. Id. at 888 .

304. Id. The defendant's "undefended assumption" of rational consumer behavior was not enough "to carry a summary judgment motion in the face of competent evidence that the assumption is false." Id. at 889 . Nor would defendant's alleged behavior be immunized by the "ancicnt and disreputable proposition" that inposing civil rights liability on banks and businesses will cause them to flee minority communities. Id. at 890 . "[T]hese assumptions must be relaxed, and perhaps, ultimately replaced, if econoinic theory is to havc any application to what happens in actual markets." Id. at 888 .

305. Id. at 889 .

306. Id. at 890 . The Honorable court required that the Plaintiffs must show that:

(1) the prices charged were systematically above-market; this could not be presumed merely from a showing that the market was distorted; (2) the purported exploiters deliberately subverted the conditions for market competition by closing off access to alternatives and information, deceptively making naive and unsophisticated people dependent on them; this could not be shown from the 
require the plaintiffs to establish intentional discrimination in addition to (1) the existence of segregated housing markets, and (2) the defendants' unreasonable exploitation of these markets. However, the Honorable court did not intend such an interpretation because it referred to the exploitation theory as distinct from intentional discrimination analysis in the final paragraph of its decision. ${ }^{307}$

Clark I suggests a better interpretation of what the Honorable court meant when it required proof that "there was racial discrimination involved" 308 in the exploitation. In Clark I, the Court applied the exploitation theory applied to market conditions resulting from a "pattern of discrimination that has no place in our society." ${ }^{09}$ Similarly, the Honorable court's articulation of the exploitation theory can be read to require that a plaintiff establish that historic discrimination created the segregated housing market that constitutes the first element of the claim. This analytic step imports the historical context of racial segregation into the housing discrimination analysis. ${ }^{310}$ Thus, if a defendant exploits market conditions not caused by past racial discrimination, a plaintiff cannot pursue redress under civil rights law. If, on the other hand, a defendant intentionally exploits market forces caused by historic racial segregation, then the defendant's conduct may constitute actionable discrimination.

Read in this light, a single firm that artificially segments the residential mortgage market to sell overpriced loans in a once-redlined neighborhood may have committed actionable discrimination. Further, since lower property values and credit scores in minority neighborhoods are the direct result of historic discrimination, a lender may be liable if it intentionally exploits either of these circumstances to sell overpriced subprime loans in such neighborhoods.

\section{A Parallel Evolution: The Reverse Redlining Theory}

In contrast to redlining-denying the extension of financial assistance or insurance to particular geographic areas based on their racial, economic, or ethnic composition- "[r] everse redlining is the practice of extending credit on unfair terms to those same communities." 311 A reverse redlining theory of discrimination is analytically similar to an exploitation theory. Indeed, the Hargraves court, one of the first to adopt the theory, cited both

\footnotetext{
mere existence of imperfect competition; and (3) there was racial discrimination involved in this exploitative process.

Id. (footnote omitted).

307. See id. at 892 .

308. Id. at 890 .

309. Clark l, 501 F.2d 324, 332 (7th Cir. 1974), cert. denied, 419 U.S. 1070 (1974).

310. Honorable, 100 F. Supp. $2 \mathrm{~d}$ at 890.

311. United Cos. Lending Corp. v. Sargeant, 20 F. Supp. 2d 192, 203 n.5 (D. Mass. 1998) (emphasis added).
} 
Clark I and Honorable for the proposition that reverse redlining violates civil rights laws such as 42 U.S.C. $\S 1982$ and the FHA. ${ }^{312}$

In Hargraves, the plaintiffs alleged that the defendants, in a scheme to ultimately foreclose on properties and resell them for substantial profit, had systematically targeted their predominantly black neighborhood with predatory loans that the defendants knew or should have known the plaintiffs could not repay. ${ }^{313}$ Although the defendants' conduct was noteworthy because of its concerted and malevolent nature, ${ }^{314}$ the reverse redlining theory articulated by the court is readily applicable to less egregious conduct. In its newly formulated approach, the court held that to state a reverse redlining claim, the plaintiffs must show: "[1] defendants' lending practices... were 'unfair' and 'predatory,' and [2] that the defendants either intentionally targeted [credit terms] on the basis of race, or that there is a disparate impact on the basis of race. ${ }^{315}$

The Hargraves court held that the plaintiffs sufficiently alleged that the defendants' loan terms were unfair and predatory, explicitly rejecting the comparison approach. ${ }^{316}$ In support of this initial conclusion, the court relied in part on Congress's recognition of the predatory lending problem ${ }^{317}$ and some of the defendants' alleged predatory practices. In the end, the court took the uncommon and pragmatic step of leaving the ultimate determination of "whether the [alleged lending practices] were unfair and predatory" 318 to the fact-finder, most likely under a reasonableness standard.

This simple and subtle move has resounding implications, as the reasonableness of any conduct is informed by the context in which it occurs. By allowing a fact-finder to determine whether a given loan's terms and conditions are sufficiently "predatory and unfair" 319 to form the basis of a discrimination claim, Hargraves permits the historical context of segregation to play a role in determining liability under the FHA. Moreover, by providing for a flexiblc, ad hoc definition of discriminatory loans, Hargraves implicitly recognizes the dynamism of "terms and conditions" discrimination. Furthermore, it acknowledges the shortcomings of

\footnotetext{
312. Hargraves v. Capital City Mortgage Corp., 140 F. Supp. 2d 7, 20 (D.D.C. 2000).

313. Id; ;ee supra text accompanying notes 4-8.

314. Hargraves, $140 \mathrm{~F}$. Supp. $2 \mathrm{~d}$ at 20.

315. Id.

316. See id.

317. See id. (referencing congressional debate surrounding the Home Ownership and Equity Protection Act of 1994 (HOEPA), Pub. L. No. 103-325, \& 152(d), 108 Stat. 2191 (codified as amended at 15 U.S.C. $\$ 1639(2000)$ )). The Act affords borrowers weak protection from predatory lenders. See supra notes 154-158 and accompanying text.

318. Honorable v. Easy Life Real Estate Sys., 100 F. Supp. 2d. 885, 888 (N.D. 111. 2000).

319. Id.
} 
legislative approaches that woodenly proscribe a set formula of terms, prices, or conditions that give unscrupulous lenders a target to evade. ${ }^{320}$

Because the reverse redlining theory still requires a plaintiff to demonstrate discrimination through the usual routes of showing intentional discrimination or disparate impact, allowing a fact-finder to decide whether a particular loan was "predatory" and "unfair" does not necessarily dismantle the analytical framework established by housing discrimination precedent. However, incorporating the traditional doctrines of discrimination into the second element of the cause of action strongly suggests that the reverse redlining theory should be used as a test of the merits, rather than another means of establishing a prima facie case. ${ }^{321}$

The traditional burden-shifting arrangement is embedded in the second element of the reverse redlining cause of action because of its reference to disparate impact. However, its operation may be altered in practice by the fact-finder's concurrent consideration of whether the loan in question was "predatory" and "unfair." It is unlikely that a fact-finder, upon concluding that a defendant's loans were "predatory" and "unfair," would also find no that there was no "less discriminatory" alternative available to the defendant. ${ }^{322}$ When compared to "predatory" and "unfair" practices, most alternatives will appear "less discriminatory."

Assuming that a fact-finder is likely to determine that there are less discriminatory alternatives to racially concentrated predatory lending, the Hargraves court's incorporation of disparate impact analysis into the reverse redlining theory becomes quite significant. ${ }^{323}$ If statistical evidence establishes a prima facie case of disparate impact, and if our assumptions about fact-finders' reasoning are valid, then, as Hargraves posits, the reverse redlining theory makes actionable the racially disparate provision of "predatory" and "unfair" loans. Liability thus hinges on a fact-finder's interpretation of "predatory" and "unfair," and this interpretation will be informed by the full context in which the loans were made.

320. See id.

321. The court outlined the elements of a reverse-redlining claim as follows:

In order to show a claim based on reverse redlining, the plaintiffs must show that the defendants' lending practices and loan terms were 'unfair' and 'predatory,' and that the defendants cither intentionally targeted on the basis of race, or that there is a disparate impact on the basis of race.

Id. It is unclear whether a plaintiff, having established the above elements, has merely set forth a prima facie case that may be rebutted by the defendant, or whether the above test constitutes a test on the merits. The difference between the two interpretations goes beyond mere scmantics. Logic works in favor of the latter interpretation, since the defendant may still provide rebuttal justifications to the discrimination element, although these justifications should be considered holistically with all cvidence tending to strengthen or undermine the plaintiff's case for liability.

322. Under a disparate impact analysis, to avoid liability a defendant must show that no less discriminatory alternative to the challenged practice exists. See supra Part III.A.2.

323. Hargraves v. Capital City Mortgage Corp., 140 F. Supp. 2d 7, 21 (D.D.C. 2000). 
In addition to Hargraves, recent case law illustrates the significance of context in establishing reverse-rcdlining claims. In Associates Home Equity Services, Inc. v. Troup, ${ }^{324}$ counterclaiming defendants in a foreclosure action for default on a home-repair loan alleged that the originator and assignec of the loan had violated, inter alia, New Jersey consumerprotection laws and the Fair Housing Act. ${ }^{325}$

There, the borrowers "laid the foundation for a reverse-redlining case by establishing that they are African Americans living in a predominately African-American neighborhood" and, through expert testimony, that the "I 1.65 percent interest rate and other terms of the loan were unjustified from an objective viewpoint, given the [plaintiffs'] credit history and favorable debt-to-income ratio." ${ }^{" 326}$ Thus, in Troup, the court permitted expert testimony into the objective reasonableness of the loan price and allowed this evidence to inform the required "unfair and predatory" determination. ${ }^{327}$ In holding that the Troups were entitled to further discovery, the court concluded that the loan's high interest rate and the context of its origination "at the very least are supportive of the Troups' claim that [the lender] participated in the targeting of inner-city borrowers who lack access to traditional lending institutions, charged them a diseriminatory interest rate and imposed unreasonable terms. ${ }^{.328}$ The court also held that the Troups were entitled to information about other loans originated by the foreclosing lender to borrowers in New Jersey ${ }^{329}$ By allowing borrowers to survive summary judgment, the reverse redlining theory permits discovery into the type of loan data that may eventually sustain a finding of liability on the merits.

Unlike Troup, which relied on geographic and economic context, Matthews v. New Century Mortgage Corp. ${ }^{330}$ illustrates the potential difficulties of using a comparison approach to establish reverse-redlining claims. There, a prima facic reverse-redlining claim requircd that the plaintiff show:

(I) that she is a member of a protected class; (2) that she applied for and was qualified for loans; (3) that the loans were given on grossly unfavorable terms; and (4) that the lender continues to provide loans to other applicants with similar qualifications, but on significantly more favorable

\footnotetext{
324. 778 A.2d 529 (N.J. 2001).

325. Id. at 534 .

326. Id. at 538 .

327. To determine the objective reaonableness of the loan the cxpert was permitted to compare the price of the loan at issue to the market rates available to borrowers with qualifications similar to those of the counterclaiming defendants. Id.

328. Id.

329. Id.

330. 185 F. Supp. 2d 874 (S.D. Ohio 2002).
} 
terms. ... . [or] that the lender intentionally targeted her for unfair loans .... 331

The Matthews plaintiffs suffered from an inherent weakness of the comparison formulation of the test: they were not even able to allege that the defendants offered loans on more favorable terms to similarly situated persons who were not members of a protected class. ${ }^{332}$ Their inability to prove this element did not prove fatal to their claim, however, because they were able to allege that the defendants intentionally targeted them for unfair loans, the alternative fourth element of the prima facie case. ${ }^{333} \mathrm{Had}$ the litigation progressed to the merits, liability likely would have turned - as it did under the Hargraves formulation-on whether the loan terms were "grossly unfair."

A potential advantage for plaintiffs in adopting the reverse-redlining comparison approach is the possibility of challenging intrafirm segmentation. If a plaintiff successfully argues that a lender-defendant consists of both a firm's prime and subprime affiliates, then the lender's primequalified minority borrowers, who receive subprime loans from a neighborhood branch, could be compared to similarly qualified white applicants, who received loans on more favorable terms through the lender's prime affiliate. ${ }^{334}$ The argument's difficulty is its reliance on a link, at some stage of the chain of inference, between race and geography. However, given courts' increased willingness to (1) hear expert testimony establishing the lasting effects of de facto segregation, ${ }^{335}$ and (2) consider empirical evidence supporting the link between race and geography, the argument is worth making.

\section{ConCLUSION}

Deep structural shifts in mortgage markets over the past two decades have greatly expanded the capital available for residential mortgage lending and have madc the goal of homeownership a reality for many. Access to fairly priced credit, however, remains inequitably distributed. Neighborhoods once excluded from mainstream credit markets are now sites of exploitation as lenders take advantage of market failures caused by historic discrimination to maximize profits. As the paradigm of housing discrimination has evolved from exclusion to exploitation, so too must fair housing

\footnotetext{
331. Id. at 886 .

332. Id. at 887 .

333. Id.

334. This is the argument accepted in Johnson v. Equicredit Corp. of Am., No. 01 C 5197, 2002 WL 448991 (N.D. Ill. Mar. 22, 2002).

335. See, e.g., Assocs. Home Equity Servs., Inc. v. Troup, 778 A.2d 529, 536 n.2 (N.J. Super. Ct. App. Div. 2001) (recounting testimony by researcher Elvin Wyly that a "dual housing finance market" existed in New Jersey for refinance and home improvement loans with "urban areas of heavy minority concentration ... being disproportionately serviced by subprime lenders").
} 
doctrine evolve. By permitting a fact-finder to consider both the historical and market context in which allegedly discriminatory loans have been made, the exploitation and reverse-redlining theories improve the efficacy of fair housing litigation in combating the harmful effects of racially concentrated subprime and predatory lending.

Litigation alone cannot offer a panacea for the economic ills created by decades of inner-city disinvestment. Aggressive enforcement of the FHA must be part of a comprehensive strategy of improving equal access to capital that involves lawmakers, lenders, and community leaders in addition to lawyers and courts. Legislative and policy proposals to strengthen regulation of subprime lending abound, such as increasing price transparency through heightened disclosure requirements, ${ }^{336}$ imposing on subprime lenders a duty of suitability akin to that currently imposed on sellers of securities, ${ }^{337}$ permitting liability of loan originators to reach holders of mortgage-backed securities, ${ }^{338}$ and developing loan products that help subprime borrowers "graduate" to the prime market. ${ }^{339}$

Such measures, however, require political will and popular support. Use of the exploitation and reverse-redlining theories to combat racially concentrated subprime lending under the FHA may thus play a critical role in the ongoing struggle for equal access to capital. Courtroom success and the accompanying public scrutiny of subprime lending will not only motivate lenders to reform, but will also raise public and political support for more comprehensive strategies. As the strength of empirical data linking race, space, and loan pricing grows, so too will the power of these new theories of housing discrimination. Successful use of the theories to gain discovery into lenders' loan data will in turn increase our understanding of these linkages. Perhaps, then, novel theories of discrimination and empirical understanding of subprime mortgage markets can work together in a self-reinforcing virtuous cycle to help combat the century-old vicious cycle of disinvestment and exploitation in America's inner cities.

336. Requiring subprime lenders to publish tables of interest rates and fees that correspond to borrower credit scores, for example, would increase price transparency and facilitate comparison shopping.

337. Engel \& McCoy, supra note 123, at 1317-66.

338. Eggcrt, supra note 116, at 640 . Eggert argues for elimination of the holder in due course doctrine as a protection for holders of mortgage backed securities.

339. HUD-TREASURY REPORT, supra note 14, at 105. 
